\title{
Z FILOLOGII ŚLEDCZEJ. MARINA CWIETAJEWA JAKO ŚWIADEK W SPRAWIE O ZABÓJSTWO IGNACEGO REISSA W ŚWIETLE DWÓCH PROTOKOŁÓW PRZESŁUCHANIA
}

\author{
GRZEGORZ OJCEWICZ \\ Uniwersytet Warmińsko-Mazurski w Olsztynie \\ Wydział Humanistyczny \\ Instytut Słowiańszczyzny Wschodniej \\ Zakład Literatur Wschodniosłowiańskich \\ ul. Kurta Obitza 1, 10-725 Olsztyn, Polska \\ e-mail: gojcew@poczta.onet.pl \\ ORCID: https://orcid.org/0000-0002-5909-270X \\ (nadesłano 27.05.2018; zaakceptowano 10.09.2018)
}

\section{Abstract \\ From Investigative Philology. Marina Tsvetaeva as a witness in the Ignace Reiss' assassination case in the light of two interrogation protocols}

The issue of the involvement of Marina Tsvetaeva (1892-1941) in the proceedings held by national authorities (the court and prefecture in Paris) in relation to the assassination of a Soviet spy Ignace Reiss (1889-1937) has never been a topic of scientific elaboration in the field of Russian studies in Poland. My article describes and provides analysis and interpretation of two interrogation protocols of the Russian poet who testified as a witness at the Paris prefecture on 22 October and 27 November 1937. Tsvetaeva's testimony, however, was focused mostly on the activities of her husband, Sergei Efron (1893-1941) as an agent rather than on the issue of the Lausanne murder. As a result, they did not bring any substantial information related to Ignace Reiss' assassination case. The protocols also contain factual mistakes regarding the events in the witness' life and the life of her daughter. It may seem that the reason for the mistakes was Tsvetaeva's poor mental, physical and intellectual health in those times of hardship. Maybe she simply played a role that she had previously prepared for herself. 


\title{
Key words
}

Marina Tsvetaeva, Sergei Efron, the assassination of Ignace Reiss, Stalin's intelligence agency in Paris.

\begin{abstract}
Abstrakt
Temat udziału Mariny Cwietajewej (1892-1941) w postępowaniu przed organami państwowymi - paryskim sądem i paryską prefekturą - w związku ze skrytobójczym zabójstwem radzieckiego agenta, Ignacego Reissa (1889-1937), nie jest naukowo opracowany w polskiej rusycystyce. W artykule opisuję, analizuję i interpretuję dwa protokoły przesłuchań rosyjskiej poetki, która zeznawała w charakterze świadka w paryskiej prefekturze 22 X i 27 XI 1937 roku. Zeznania Cwietajewej bardziej jednak dotyczą agenturalnej działalności jej męża, Siergieja Efrona (1893-1941), aniżeli kwestii mordu w Lozannie i dlatego nie wniosły niczego istotnego do sprawy o zabójstwo Ignacego Reissa. W protokołach utrwalono przy okazji błędy merytoryczne związane głównie z biografią samego świadka, jak też jej córki. Wydaje się, że przyczyną istotnych pomyłek może być zła kondycja psychofizyczna i intelektualna Cwietajewej w tamtych trudnych dniach, a ona sama odegrała rolę, do której się wcześniej przygotowała.
\end{abstract}

\section{Słowa kluczowe}

Marina Cwietajewa, Siergiej Efron, zabójstwo Ignacego Reissa, stalinowskie służby agenturalne w Paryżu.

\section{Wstęp}

Temat udziału Mariny Cwietajewej (1892-1941) w postępowaniu przed organami państwowymi - paryskim sądem i paryską prefekturą - w związku ze skrytobójczym zabójstwem radzieckiego agenta, Ignacego Reissa (1889-1937), do jakiego doszło 4 września 1937 roku w Lozannie ${ }^{1}$, należy w polskiej rusycystyce do kwestii całkowicie niezbadanych ${ }^{2}$. Inaczej zupełnie, gdy chodzi o prozę czy poezję tej wybitnej pisarki i tłumaczki Srebrnego Wieku³. Problem jest jednak intrygujący i wart podjęcia roz-

1 O tej sprawie pisałem w poprzednim roczniku „Studia Rossica Gedanensia”: G. Ojcewicz. Z filologii śledczej. Praca agenturalna stalinowskich służb specjalnych za granica na przykładzie sprawy o zabójstwo Ignacego Reissa (Ojcewicz, 2017, s. 297-332).

2 Odmiennie od rusycystyki rosyjskiej, gdzie temat ten był podejmowany, lecz trudno powiedzieć, aby został wszechstronnie zbadany i w sposób wyczerpujący. Zob. np. prace Irmy Kudrowej: Гибель Маринь Цветаевой (Кудрова, 1997); Путь комет. Жизнь Маринь Цветаевой (Кудрова, 2002); Жизнь Марины Цветаевой: Документальное повествование (Кудрова, 2002); Марина Цветаева: беззаконная комета (Кудрова, 2016). Zob. także opracowanie Anny Saakianc: Жизнь Цветаевой. Бессмертная птица-феникс (Саакянц, 2002). Zob. jeszcze polski przekład jednej z książek Irmy Kudrowej: Tajemnica śmierci Mariny Cwietajewej (Kudrowa, 1998).

3 Zob. np.: Z. Maciejewski. Proza Maryny Cwietajewej jako program i portret artysty (Maciejew- 
poznawczego wysiłku analityczno-interpretacyjnego, ponieważ może rzucić on nowe światło na postać nietuzinkowej kobiety, nie z własnej woli uwikłanej w konflikt sumienia $\mathrm{z}$ powodu następstw agenturalnych spraw swojego męża, radzieckiego szpiega, stalinowskiego werbownika i agenta NKWD w jednej osobie - Siergieja Efrona (1893-1941), podejrzewanego przez służby szwajcarskie i francuskie o udział w zabójstwie Reissa i innych akcjach tajnych służb Kremla we Francji.

Gdy jesienią 1937 roku wyszła na jaw agenturalna działalność Efrona, aura międzynarodowego skandalu, która silnie wzburzyła paryskie środowisko rosyjskich emigrantów, dotknęła także Cwietajewą, a w konsekwencji - zmusiła ją do zeznawania nieprawdy lub przemilczania prawdy przed sądem i prefekturą, by ratować męża, siebie i rodzinę. Taka obiektywnie naganna moralnie postawa poetki, lecz akceptowalna z ludzkiego punktu widzenia, nie mogła być obojętna ani dla władz francuskich, ani tym bardziej dla stalinowskiego reżimu, na którego rzecz gorliwie pracował Siergiej Efron ${ }^{4}$. Przeciwko Cwietajewej gwałtownie zwróciło się środowisko emigracyjne. Natychmiast mocno ucierpiała jej popularność autorska. Zaczęły się dotkliwe utrudnienia związane z drukiem tekstów i jawne okazywanie ostracyzmu. Dalsza perspektywa życia w Paryżu nie napawała optymizmem. I mimo że trwało wciąż śledztwo prowadzone w Lozannie i Paryżu, a zabójcy Ignacego Reissa już dawno znajdowali się w Moskwie, mimo że nie ustalono jeszcze roli samego Siergieja Efrona w danym przestępstwie, jak też w porwaniu generała Jewgienija Millera (1867-1939), sama przynależność do najbliższego grona stalinowskiego agenta oznaczało społeczne napiętnowanie i uruchomienie dotkliwej lawiny szykan. W Cwietajewej dojrzewała gwałtownie - zdecydowanie wbrew jej najgłębszemu wewnętrznemu sprzeciwowi decyzja o konieczności powrotu do ZSRR, by zachować słabnącą z dnia na dzień więź z rodziną. Narastało stopniowo prorocze przeczucie, że uda się do Kraju Rad po własną śmierć.

O samych przesłuchaniach Cwietajewej przed paryskimi organami sądowo-śledczymi wiemy stosunkowo niewiele, a i to, co do nas dotarło w formie udokumentowanych przekazów, wymaga sporej ostrożności interpretacyjnej. Nie można bowiem przyjąć ze stuprocentową pewnością, że relacje świadków pokrywają się z rzeczywistością, że nie rejestrują przy okazji pewnej projekcji wydarzeń, jaka była właściwa i pożądana w oczach samej Cwietajewej, ratującej swój wizerunek wśród znajomych. Na przykład rosyjski emigrant, pisarz i publicysta Mark Słonim (1894-1976), tak zanotował słowa Cwietajewej o pobytach w prefekturze Paryża:

W czasie przesłuchań w policji francuskiej (Biuro Bezpieczeństwa Narodowego) cały czas mówiła o uczciwości męża, o zderzeniu się długu z miłością i cytowała z pamięci czy to Corneille’a,

\footnotetext{
ski, 1982); S. Pollak, Wstęp do: M. Cwietajewa, Poezje (Pollak, 1968); A. Majmieskułow, Провода под лирическим током. Цикл Марины Цветаевой «Провода» (Majmieskułow, 1992); Е. Janczuk, Język poetycki Mariny Cwietajewej (Janczuk, 2013); A. Piwkowska, Wyklęta. Poezja i miłość Mariny Cwietajewej (Piwkowska, 2017).

4 Efronowie planowali przecież rodzinny wyjazd do ZSRR, co ostatecznie się powiodło. Najpierw wyjechała córka Ariadna (15 III 1937), potem Siergiej Efron (X 1937), a 18 VI 1939 roku dołączyła do rodziny Marina z synem Gieorgijem (1925-1944).
} 
czy to Racina (ona sama potem opowiadała o tym najpierw M. N. Lebiediewej ${ }^{5}$, a potem mnie). Najpierw urzędnicy myśleli, że ona ich zwodzi i udaje, lecz kiedy zaczęła recytować im francuskie przekłady Puszkina i swoich własnych wierszy, ci zwątpili w jej zdrowie psychiczne, a gdy zjawili się na pomoc doświadczeni specjaliści ds. emigracji, to rekomendowali ją jako „cette folle Russe"6.

Cwietajewa nie kryła się, jak widać z dzieleniem wrażeniami z przesłuchania w charakterze świadka w tak głośnej sprawie, jak zabójstwo Ignacego Reissa. Świadczy o tym chociażby list napisany przez nią 26 października 1937 roku do Ariadny Berg (1899-1979)7 , dwa tygodnie po ucieczce Efrona za granicę, w którym poetka lakonicznie donosi:

Teraz więcej pisać nie mogę, ponieważ jestem całkiem przybita z powodu wydarzeń, które także są nieszczęściem, a nie winą. Powiem Pani, co rzekłam na przesłuchaniu: „—C’est le plus loyal, le plus noble et le plus humain des hommes. - Mais sa bonne foi a pu être abusée. — La mienne en lui - jamais".

5 Z rodziną Lebiedziewów - Margaritą Nikołajewną (1880-1958), Władimirem Iwanowiczem (1884-1956) i ich córką Iriną Władimirowną - Cwietajewa była prawdziwie zaprzyjaźniona, a Ariadna Efron przez długie lata utrzymywała równie przyjacielskie kontakty z Iriną. Poetka znajdowała u nich nie tylko za każdym razem wsparcie finansowe, lecz przede wszystkim niezawodną pomoc duchową. W 1997 roku zupełnie przypadkowo odkryto jedną z nieznanych prac Cwietajewej, którą był rękopis przekładu na język francuski szkicu Władimira Lebiedziewa Perast (zob. Лебедев, 1997; zob. np.: http://www.mysilverage.ru/2015/11/29/lebedev-v-perast-perevod-na-fr-m-cvetaevoj/ (15.05.2018)). Tu i dalej, jeśli nie zaznaczono inaczej, przypisy pochodzą ode mnie.

${ }^{6}$ Cette folle Russe - fr. ta szalona Rosjanka. Cyt. za: И. Кудрова. Приложение I. Протоколь допросов Марины Цветаевой в Префектуре Парижа (1937 год). В: Кудрова, 1997. Tu i dalej podaję w tłumaczeniu własnym. Por. Саакянц, 2002, s. 715.

7 Zob. пр.: Цветаева М. И. Письма к Ариадне Берг: (1934-1939) (Цветаева, 1990). Redaktor tomu, Nikita Aleksiejewicz Struve (1931-2016), francuski rusycysta, wydawca i thumacz, badacz dziejów rosyjskiej emigracji oraz kultury Rosji, w przedmowie do danej książki podkreślił, że „Każda notatka Cwietajewej, chociażby najmniej treściowo znacząca (odwołanie terminu spotkania, na przykład) świadczy o literackim podejściu do słowa, nie mówiąc już o obszernych listach, będących utworami prawdziwej sztuki, przy czym nie tylko słownej”. Struve zamieścił w danym tomie 74 francusko- i rosyjskojęzyczne listy Mariny Cwietajewej do Ariadny Berg, do tej pory nieznane nawet cwietajewologom. Badacz zapewnia, że listy te odkrywają nowego adresata i istotnie uzupełniają naszą wiedzę o ostatnich pięciu, najbardziej dramatycznych i samotnych latach emigracyjnego życia poetki. Odsłaniają jednocześnie ukryte obszary jej duszy i przeżyć duchowych.

8 Суt. za: И. Кудрова, Приложение I... „То najuczciwszy, najszlachetniejszy, najbardziej ludzki człowiek. - Lecz jego zaufanie mogło zostać nadużyte, moje zaufanie do niego pozostanie niezachwiane”. Także w liście do Stalina Cwietajewa odważnie i z przekonaniem będzie bronić honoru męża, uznając wszelkie wysunięte wobec niego zarzuty za krzywdzące nieporozumienie. Poetka m.in. napisze do wodza bolszewików następujące zdania: „Nie wiem, o co oskarżają mojego męża, lecz wiem, że do żadnej zdrady, hipokryzji i wiarołomstwa nie jest on zdolny. Znam go: 1911-1939 lata - prawie 30 lat, lecz to, co o nim wiem, znałam już od pierwszego dnia: że jest to człowiek o największej czystości, ofiarności i odpowiedzialności. To samo powiedzą o nim przyjaciele i wrogowie" (суt. za: Кудрова, 1997). 
A w kolejnym liście do tejże Ariadny Berg z 2 listopada 1937 roku Cwietajewa pisze:

Cokolwiek by Pani słyszała o moim mężu czy czytała niedorzecznego - proszę nie wierzyć, jak nie wierzy temu ani jeden (chociażby najbardziej „prawicowy”) spośród - nie tylko znających, ale - spotykających. (...) O mnie: Pani przecież wie, że żadnych „spraw” nie miałam (to, między innymi, wiedzą także w Biurze Bezpieczeństwa Narodowego, gdzie przetrzymali nas z Murem9 od rana do wieczora) - i nie tylko z powodu największej niezdolności, lecz z najgłębszego obrzydzenia do polityki, którą cała - poza najrzadszymi wyjątkami - mam za bagno (суt. za: Кудрова, $1997)^{10}$.

Kim była Ariadna Berg, że zasłużyła sobie na wielką szczerość Cwietajewej, że stała się empatyczną powiernicą najskrytszych tajemnic rodzinnych wybitnej pisarki w tamtych gorzkich dniach? Ariadna Emiljewna Voltere urodziła się w Orle. Matka była Rosjanką, ojciec - Belgiem, inżynierem, który przyjechał budować pierwsze tramwaje dla carskiego imperium. Ariadna ukończyła gimnazjum w Carskim Siole. Po rewolucji październikowej rodzina wyemigrowała przez Władywostok, Japonię i USA do Francji. W 1920 roku Ariadna wyszła za mąż za urodzonego w Rydze Nikołaja Berga (1888-1937), prawnika z wykształcenia, starszego od niej o 11 lat, pracującego w Lidze Narodów. We Francji przyszły na świat trzy córki: Maria-Henrietta (Butia, 1924-1937), Wiera i Jelena (Lula).

Ariadna Berg poznała Marinę Cwietajewą pod koniec 1934 roku, najprawdopodobniej u wspólnych znajomych - kompozytora Thomasa de Hartmanna (1885-1956) - lub na jakimś wieczorze. Jak podkreśla Nikita Struve, młoda kobieta, która sama parała się literaturą i pisała po francusku wiersze, zainteresowała się autoprzekładem Cwietajewej poematu Junak (Молодеи, 1924) i zaproponowała jej pomoc w znalezieniu wydawcy. Rozpoczęta w języku francuskim korespondencja zamieniła się w rosyjskojęzyczną wymianę zdań, a pierwsze spotkania szybko przerodziły się w trwałą przyjaźń. Czy na jej zadzierzgnięcie mogła mieć zbieżność imion - Ariadna - pierworodnej córki z nowo poznaną osobą? Cwietajewa zachęcała Berg do publikowania swoich wierszy, czuła w tej kobiecie podobieństwo do siebie, zbieżność charakterów i losów. W 1937 roku, fatalnym dla obu pań, w styczniu zmarł Nikołaj Berg, a w październiku - utalentowana najstarsza córka, Maria-Henrietta. Cwietajewa zaś musiała się zmagać wtedy ze sprawą Reissa, nagłym zniknięciem Siergieja Efrona i przesłuchaniami przed francuskimi organami wymiaru sprawiedliwości oraz ścigania.

Wdowa Berg wyjeżdża do Belgii, by być bliżej brata. Bezpośrednie spotkania z Cwietajewą będą więc odtąd rzadkością, lecz zaufanie nie osłabnie. Można nawet mówić o wzajemnej wierności dwóch kobiet wobec siebie bez względu na towarzyski bojkot poetki zapoczątkowany jesienią 1937 roku. Przed wyjazdem do ZSRR pisarka powierza jej na przechowanie część swojego archiwum oraz kilka bezcennych przedmiotów, w tym - ikonę. Listy Cwietajewej zachowały się w całości, a te od Ariadny Berg - od połowy 1938 roku. Losy pozostałego archiwum nie są znane. Być może, sugeruje Nikita Struve, że Ariadna Berg nie zdążyła zajść po to archiwum do rodzi-

\footnotetext{
9 Tj. synem, Gieorgijem Efronem.

10 Podobnie u Anny Saakianc: „(...) Marina Cwietajewa (...) nienawidząc polityki jako takiej, nie rozeznawała się i nie chciała się w niej rozeznawać” (Саакянц, 2002, s. 712 i 716).
} 
ny Lebiedziewów przed ich wyjazdem do Ameryki. A jeśli tak, kontynuuje badacz, najprawdopodobniej archiwum Cwietajewej spotkał ten sam los, co archiwum Lebiedziewów: obydwa przepadły po zalaniu piwnicy wodą. Lecz równie dobrze mogły zostać utracone pod koniec wojny, gdy w Paryżu zaginęło wiele rzeczy należących do Ariadny Berg, albo podczas jej przeprowadzki z Brukseli do Szwajcarii i ponownie ze Szwajcarii do Brukseli.

Oczywiście, dzisiaj nikt już nie jest w stanie ani potwierdzić, ani zanegować nie tylko przebiegu samych przesłuchań - liczby osób biorących w nich udział, atmosfery, występowania potencjalnych nacisków, sugestii itp. - ale także przytoczyć wszystkich pytań, jakie wtedy padały, i określić, jakie były pełne odpowiedzi świadka. Nikt nie jest także w stanie ani potwierdzić, ani zaprzeczyć temu, jak Marina Cwietajewa zachowywała się w trakcie składania zeznań: normalnie, ze spokojem i godnością czy też dała podstawy, by nazwać ją - łagodnie mówiąc - „szaloną Rosjanką”? Czy zapewniała gorąco o szlachetności i uczciwości Siergieja Efrona? Czy recytowała własne przekłady cudzych wierszy i wybrane fragmenty tłumaczeń swojej poezji? Ile jest prawdy, a ile miłego uchu zmyślenia w relacji Marka Słonima, powołującego się dodatkowo na Margaritę Lebiedziewą?

Niewykluczone, że informacja o udziale Siergieja Efrona w agenturalnych rozgrywkach stalinowskich służb specjalnych, zwłaszcza na terenie Paryża, nigdy nie ujrzałaby światła dziennego, gdyby nie błąd strategiczny: nagłe zniknięcie szpiega w październiku 1937 roku. Przy czym zniknięcie wcześniejsze najprawdopodobniej o kilka dni niż zeznaje oficjalnie, potwierdza i podpisuje Cwietajewa w protokole przesłuchania świadka. Jak bowiem zauważa Anna Saakianc (1932-2002), literaturoznawczyni, której ustaleniom badawczym wolno ufać, do ucieczki Efrona mogło dojść już w niedzielę 10 października 1937 roku. Anna Saakianc pisze:

Na początku października sprawy przybrały taki obrót, że Siergiej Jakowlewicz, podobnie jak małżeństwo Klepininów, był zmuszony do zniknięcia bez śladu. Wszyscy troje (on, Marina Iwanowna, Mur) przyjechali do Muni Bułhakowej, po mężu - Stepurżynskiej; być może przez pewien czas przebywali u niej ${ }^{11}$, po czym mąż, szofer, powiózł ich w kierunku Hawru; nie dojeżdżając do miasta, Siergiej Jakowlewicz pośpiesznie wysiadł z auta... Miało to miejsce, najprawdopodobniej, 10 października Siergiej potajemnie zbiegł. Jego ucieczkę zorganizował, rozumie się, radziecki wywiad. Droga prowadziła do Moskwy (Саакянц, 2002, s. 712. Pogr. - G. O.).

Całą tę tajną akcję NKWD i jej pierwsze konsekwencje tak zaś przekonująco relacjonuje Irma Kudrowa (Kudrowa, 1998, s. 15):

Efrona przywieziono do kraju potajemnie, również specjalnym rejsem motorowca, noszącego imię „Andriej Żdanow” - w grupie osób zamieszanych, jak podejrzewano, w tak zwaną „sprawę Reissa”. Czworo z tej grupy (a może cała grupa składała się tylko z tych osób) można teraz wymienić z nazwiska. Byli to: Siergiej Efron, Nikołaj Klepinin, Jewgienij Łarin i Paweł Pisariew. Jak się dopiero dzisiaj wyjaśniło, ten dobór był dosyć przypadkowy, żeby nie powiedzieć dziw-

11 I mógł to być właśnie czas na ustalenie wersji „nagłego” zniknięcia Siergieja Efrona lub poinformowania przez Efrona wszystkich obcnych o tym, co mają mówić, gdy sprawa wyjdzie na jaw. Efron zaś otrzymał zapewne taką instrukcję od NKWD, bo przecież sam nie miał prawa wymyślać wersji wydarzeń. Na NKWD jako źródło tej właśnie wersji wydarzeń zwraca także uwagę Irma Kudrowa (zob. Кудрова, 1997). 
ny. Albowiem później, na przesłuchaniach, Klepinin będzie upierać się przy tym, że ani on, ani Efron nie mieli bezpośrednio nic wspólnego z akcją przeciw Reissowi, wykonując inne zadania wywiadu. Przypadkowy dobór grupy może znajdować wyjaśnienie w fakcie, iż wyżsi funkcjonariusze NKWD, rzeczywiście, odpowiedzialni za przeprowadzenie „akcji”, zostali już wcześniej odwołani do Moskwy. Ich ślady w Paryżu próbowali zatrzeć ludzie niezbyt zorientowani w szczegółach całej historii.

Ponieważ jednak grupa została przywieziona potajemnie - wszystkim nadano nowe nazwiska, Siergiej Jakowlewicz nie jest już Efronem tylko Andriejewem, Klepinin to Lwow, a Łarin - Klimow.

Oficjalie utrzymuje się, że Efron zniknął gdzieś w Hiszpanii - taką przyjęto wersję. Sens tego jest jasny - jeżeli, podobnie jak pozostali, jest tutaj, w Moskwie, to stanowi to argument potwierdzający udział Kraju Rad w „sprawach” Reissa i porwania generała Millera. Bowiem zniknięcie całej czwórki z Francji zbiegło się akurat z momentem, kiedy francuska policja wpadła na „,radziecki trop" w obydwu sprawach.

Nowo przybyłym nie zaleca się zawierania nowych znajomości. Z dawnymi przyjaciółmi, sprzed emigracji, też wolno spotykać się tylko sporadycznie.

Przesłuchanie Mariny Cwietajewej w charakterze świadka z dnia 22 października 1937 roku poprzedziły niespodziewane odwiedziny czterech inspektorów francuskiej policji, którzy rankiem dokonali starannego i długotrwałego przeszukania pomieszczeń w mieszkaniu przy ulicy Jeana-Baptisty Potina 65. Co ważne z punktu widzenia dalszych wydarzeń, już wtedy urzędnicy państwowi pobrali do celów procesowych prywatne dokumenty Siergieja Efrona i jego korespondencję. Według Anny Saakianc, policja zabezpieczyła dokumenty, które włożono do dwóch walizek, a więc - wydaje się, że było ich dostatecznie wiele, by móc dokonać wiarygodnej analizy grafologicznej; zabezpieczone dokumenty miały potem zaginąć... (Саакянц, 2002, s. 713). Z pewnością „wizyta” funkcjonariuszy i przeprowadzone przez nich czynności nie wpłynęły uspokajająco na samopoczucie Cwietajewej. A tego samego dnia czekało ją jeszcze wielogodzinne przesłuchanie w paryskiej prefekturze - od rana do wieczora, jak często powtarzała znajomym, dzieląc się wrażeniami z pobytu w mrocznym gmachu.

\section{Dyskusja}

Ówczesny francuski protokół przesłuchania, podobnie zresztą jak większość protokołów na całym świecie, składał się z części graficznie zamkniętej, standardowej, i z większej części - otwartej. Część graficznie zamknięta jest zestawem wierszy z opuszczonymi w nich miejscami na wpisanie bieżącej informacji związanej z konkretną sprawą. Część otwarta to przestrzeń do wypełnienia zeznaniami świadka, teoretycznie może liczyć dowolną liczbę stron. Nietypowe w danym formularzu jest rozdzielenie go na dwie kolumny: pierwsza, licząca ok. $6 \mathrm{~cm}$, zawiera oprócz standardowej grafiki, czyli informacji o instytucji przeprowadzającej czynność procesową, także wolne pole, na którym znajdują się istotne dane poboczne. Tego typu rozwiązanie graficzne druku procesowego jest dość niebezpieczne dla składającego zeznanie, ponieważ już po podpisaniu dokumentu w każdej chwili można było na lewym marginesie maszynowo lub odręcznie dopisać coś, co wcale nie musiało należeć do treści zeznań świadka. Druga kolumna protokołu jest znacznie szersza od pierwszej i liczy 
od 12,5 do 13,5 cm, a różnice w szerokości wynikają z długości wierszy, którą dyktowały umiejętności maszynistki.

Z danych zawartych w standardowych nagłówkach lewej i prawej kolumny protokołu wynika, że jest on własnością Republiki Francuskiej, którą reprezentuje Ministerstwo Spraw Wewnętrznych, a ściślej - w danym przypadku - Generalne Biuro Bezpieczeństwa Narodowego, jeszcze dokładniej - jako organ wykonawczy czynności procesowych - Inspekcja Generalna, której był podporządkowany Wydział Spraw Kryminalnych.

Analiza protokołu przesłuchania nie może przebiegać bez świadomości, że nie jest on zapisem stenograficznym, ale raczej szczupłą wypadkową zeznań świadka i tego, co do protokołu polecił zapisać prowadzący przesłuchanie. To z kolei sugeruje, że nie wszystkie kwestie, jakie pojawiały się w trakcie przesłuchania i składania zeznań, są w dokumencie - dla dobra sprawy z punktu widzenia służb specjalnych - ujęte. Tak więc, na protokoły przesłuchań Mariny Cwietajewej należy patrzeć nie jak na pełny i wyczerpujący dokument w określonej sprawie, lecz jak na tekst, który swoją zawartością ma służyć postępowaniu wyjaśniającemu.

\section{Protokół przesłuchania Mariny Cwietajewej z 22 października 1937 roku}

Tekst przesłuchania Mariny Cwietajewej w Prefekturze Paryża w dniu 22 października 1937 roku został opublikowany w pracy Petera Hubera i Daniela Künzi (1958) Paris dans les années 30. Sur Serge Efron et quelques agents du NKVD (zob. Huber, Künzi, 1991, s. 285-310). Przekładu na język rosyjski na podstawie wymienionego źródła dokonała Irma Kudrowa i ogłosiła drukiem jako aneks np. w książce Śmierć Mariny Cwietajewej (Кудрова, 1997).

Ponieważ nie dysponuję kopią tego przesłuchania, poniżej odwołuję się do wiedzy przekazanej przez Irmę Kudrową (1929). Tak więc, część wstępna protokołu przesłuchania świadka, w której są prezentowane instytucje państwowe, wygląda tak samo w dokumentach z 22 października 1937 i z 27 listopada 1937 roku. Tym razem sprawa, której numeru nie poznajemy, toczy się przeciwko Pierre’owi Ducommetowi ${ }^{12}$ i innym osobom oskarżonym o zabójstwo i współudział w nim. Świadkiem jest pani Efron, z domu Cwietajewa Marina, lat 43, zamieszkująca pod adresem: 65, ul. J.-B. Potina w Vanves (Sekwana). Przesłuchanie ma miejsce 22 października 1937 roku $^{13}$. Dalej wiersze sformalizowane przeplatają się z zapisem maszynowym, czyli z treścią aktualizującą przebieg przesłuchania:

\footnotetext{
12 Pierre Ducommet (1902-1961). Był francuskim fotografem, zwerbowanym do stalinowskiej służby wywiadowczej przez Nikołaja Siergiejewicza Pozniakowa w 1936 roku. Należał do grupy operacyjnej utworzonej latem 1937 roku w Paryżu w celu wyśledzenia i zabójstwa Ignacego Reissa. Został aresztowany przez policję francuską i jako oskarżony złożył obszerne wyjaśnienia. W więzieniu przebywał 13 miesięcy. Zwolniono go z powodu niezatrzymania głównych sprawców zabójstwa. Posługiwał się partyjnym pseudonimem „Bob”.

13 Dzień ten wypadł w piątek.
} 
My, Papin Robert, komisarz policji mobilnej ${ }^{14}$ Wydziału Spraw Kryminalnych Inspekcji Generalnej (Generalne Biuro Bezpieczeństwa Narodowego) w Paryżu, oficer policji sądowej, na polecenie pomocnika Prokuratura Republiki przesłuchujemy panią Efron, z domu Cwietajewą, urodzoną 31 lipca 1894 roku w Moskwie, z obecnie już nieżyjących Iwana i Marii Bernskich, literatki, mieszkającej w Vanves, w domu nr 65 przy ulicy J.-B. Potina, która, złożywszy przedtem przysięgę, zeznała, co następuje:

Zarabiam na życie dzięki swojemu zawodowi, współpracuję z czasopismami „Russkije zapiski” i „Sowriemiennyje zapiski”, zarabiam od sześciuset do ośmiuset franków na miesiąc. Mój mąż, dziennikarz, drukuje artykuły w piśmie „Nasz Sojuz”, który jest wydawany przez Związek Powrotu"15 i ma siedzibę przy ulicy de Boissy w Paryżu ${ }^{16}$.

$\mathrm{Z}$ tego, co mi wiadomo, mąż chodził tam do pracy codziennie od samego momentu powstania Związku. Moja córka Ariadna, urodzona 5 września 1913 roku w Moskwie, także pracowała $\operatorname{tam}^{17}$ jako artystka. W kwietniu ${ }^{18}$ tego roku porzuciła stanowisko i powróciła do Rosji. Obecnie przebywa w Moskwie i pracuje w redakcji francuskiego tygodnika, wychodzącego w tym mieście - „Revue de Moscou”.

„Związek Powrotu”, jak na to wskazuje sama nazwa, stawia sobie za cel niesienie pomocy naszym rodakom, rosyjskim emigrantom, którzy znaleźli schronienie we Francji, w powrocie do Rosji.

$14 \mathrm{~W}$ oryginale występuje w tym miejscu związek wyrazowy „Police mobile”, co daje podstawy, by przetłumaczyć go jako „policja mobilna”, lecz w żadnym razie nie jako - co znajduję w książce Irmy Kudrowej - „policja drogowa” czy „policja lotna”, ponieważ w terminologii polskiej „policja lotna” jest synonimem policji drogowej. Francuska policja mobilna (Brigades régionales de police mobile) zajmowała się sprawami kryminalnymi i przestępstwami natury prawnej. Znana była także pod nazwą „Brygady Tygrysa” (Les brigades du Tigre). Działalność brygad spopularyzował zarówno we Francji, jak i w Polsce serial sensacyjno-kryminalny, emitowany w latach 1974-1983, pod tym właśnie tytułem. Zob. np.: https://fr.m.wikipedia.org/wiki/Brigades_régionales_de_police_mobile (12.05.2018).

15 „Związek Powrotu” („Союз возвращения”) powstał w Paryżu w 1925 roku. W latach 40. zmienił nazwę na „Związek Powrotu do Ojczyzny” („Союз возвращения на Родину”), a jeszcze później na „Związek Przyjaciół Radzieckiej Ojczyzny” („Союз Друзей Советской Родины”) i jednocześnie silnie się zradykalizował ideologicznie, uzależniając w ogromnym stopniu od materialnej pomocy Związku Radzieckiego, a także stając się przykrywką Kremla w pozyskiwaniu nowych agentów NKWD. W latach 1930-1935 sekretarzem organizacji był Jewgienij W. Łarin, a od 1937 - Aleksandr Aleksandrowicz Twieritinow (1897-1942). Obydwaj zostali poddani represjom politycznym po powrocie do ZSRR. Na przykład Twieritinow zmarł w nieznanych okolicznościach w obozie NKWD podczas odbywania kary 8 lat pozbawienia wolności na podstawie słynnego art. 58 - podejrzenie o działalność kontrrewolucyjną i szpiegowską). Zob. jeszcze: А. Тверитинов. Александр Александрович Тверитинов. Крестный путь на Родину, http://www.history-ryazan.ru/node/5880 (16.05.2018); https://sites.google.com/t-n-v.com/aru/б-и-журавлев.а-а-тверитинов (16.05.2018).

16 Siergiej Efron, który od 1934 roku był na etacie NKWD, także zasilał budżet domowy setkami franków na miesiąc, których nie mógłby zarobić, gdyby parał się tylko tym zajęciem, o którym zeznaje Cwietajewa. To sugeruje, że poetka musiała się raczej zastanawiać nad źródłem jego przychodów, ponieważ była kobietą nad wyraz bystrą, i być może zdawała sobie jednak doskonale sprawę, skąd one pochodzą. Czy racjonalna byłaby wszak rezygnacja z pieniędzy w sytuacji, gdy budżet domowy nie wyglądał imponująco, a potrzeby materialne stale rosły?

17 Czyli w redakcji czasopisma „Nasz Sojuz”.

18 W rzeczywistości wyjazd miał miejsce 15 III 1937 roku, więc odejście z redakcji nie mogło nastąpić w kwietniu. 
Nikogo z kierownictwa tej organizacji nie znam, jednakże rok albo dwa lata temu poznałam niejakiego pana Afanasowa ${ }^{19}$, członka tej organizacji, który wyjechał do Rosji nieco ponad rok temu. Znałam go, ponieważ nie jeden raz przychodził do nas do domu, by spotkać się z mężem. Mój mąż był oficerem Białej Armii, lecz od czasu naszego przyjazdu do Francji, w 1926 roku $^{20}$, jego poglądy się zmieniły. Był redaktorem gazety „Jewrazija”, wychodzącej w Paryżu i wydawanej, jak się wydaje, w Clamart czy gdzieś w pobliżu ${ }^{21}$. Mogę powiedzieć, że ta gazeta się już nie ukazuje. Osobiście nie zajmuję się polityką, lecz mi się wydaje, że już od dwóch-trzech lat mój mąż jest zwolennikiem obecnego reżimu rosyjskiego.

Od początku rewolucji hiszpańskiej mój mąż stał się płomiennym obrońcą republikanów i uczucie to nasiliło się we wrześniu tego roku, gdy odpoczywaliśmy w Lacanau-Océan, w Gironde, gdzie byliśmy świadkami masowego przybycia uciekinierów z Santadera. Od tej pory zaczął wyrażać pragnienie, by wyjechać do Hiszpanii i walczyć po stronie republikanów. Wyjechał z Vanves 11-12 października bieżącego roku i od tego czasu nie mam o nim wieści. Tak więc nie mogę Panu powiedzieć, gdzie teraz przebywa i nie wiem, czy wyjechał sam czy z kimś jeszcze.

Nie znam nikogo wśród znajomych męża o imieniu „Bob”, nie znam także Smirienskiego ${ }^{22}$ ani Rollanda Marcela.

Pod koniec lata 1936 roku, w sierpniu lub wrześniu, pojechałam na wakacje z synem Gierogijem (urodzonym 1 lutego 1925 roku w Pradze) do moich rodaków, do rodziny Sztrange, którzy mieszkają na zamku d’Arcine w Saint-Pierre-de Rumilly (Górna Sabaudia) ${ }^{23}$.

19 Nikołaj Wanifatjewicz Afanasow (1902-1941) był rosyjskim emigrantem. Przyjaźnił się z Siergiejem Efronem od 1918 roku. W czasie wojny domowej w Rosji walczył po stronie białych. Opuściwszy Rosję, udał się do Bułgarii, gdzie pracował jako górnik i drwal. Po przyjeździe do Francji osiedlił się w Grenoble, podejmując się dorywczo pracy szoferskiej, większość czasu pozostawał jednak bez zatrudnienia. Do wywiadu radzieckiego został zwerbowany w 1934 roku, sam zaś zwerbował Marka Zborowskiego, który został później sekretarzem Lwa Siedowa (1906-1938), syna Lwa Trockiego (1879-1940). Do ZSRR powrócił w 1936 roku i zamieszkał w Kałudze. Utrzymywał kontakty m.in. z fanatyczną komunistką i agentką INO NKWD, Wierą Guczkową-Traill (1906-1986), również zamieszaną w sprawę zabójstwa Ignacego Reissa, Siergiejem Efronem (teraz: Andriejewem). Aresztowany na początku 1940 roku, rozstrzelany 28 lipca 1941 w Moskwie.

20 Efronowie przyjechali do Paryża w 1925 roku.

21 Gazetę „Jewrazija” („Евразия”) wydawali w Paryżu lewicowi eurazjaci w okresie od listopada 1928 roku do września 1929.

22 Dmitrij Michajłowicz Smirienski (vel Rolland Marcel, 1897 - po 1947) był rosyjskim emigrantem, wcześniej związany z ruchem białych. Do Francji przybył w 1919 roku. Podjął pracę w fabryce Renault. Wstąpił do Francuskiej Partii Komunistycznej i został członkiem „Związku Powrotu”. Zwerbowany do pracy agenturalnej przez Siergieja Efrona. Wchodził w skład grupy operacyjnej, która zajmowała się śledzeniem Lwa Siedowa, następnie zaś - poszukiwaniem i zabójstwem Ignacego Reissa. Od 10 V 1932 do 24 XII 1938 był oficjalnie zatrudniony jako szofer w Przedstawicielstwie Handlowym ZSRR z siedzibą w Paryżu. W związku ze sprawą Ignacego Reissa przebywał w szwajcarskim więzieniu. Do Związku Radzieckiego powrócił najprawdopodobniej w styczniu 1939; rok później został aresztowany przez NKWD. O dalszych losach Dimitrija Smirienskiego zob. np.: В. Вейхман Каждый день я прихожу на пристань (Вейхман, 2008).

23 O właścicielach zamku i jego gościach-agentach NKWD zob. np.: Тени замка Арсин; http:// www.travel-journal.ru/phenomenons/2/576/ (6.06.2017). 
Małżonkowie Sztrange prowadzą pod wskazanym adresem pensjonat rodzinny. Mają syna Michela ${ }^{24} \mathrm{w}$ wieku 25-30 lat, który para się literaturą. Mieszka zwykle nie w Paryżu, lecz u rodziców. Nie wiem, czy często on tutaj bywa i nie wiem, czy nadal utrzymuje kontakty z moim mężem. Mąż prawie nikogo nie przyjmował w domu i nie wszystkie jego znajomości są mi znane.

Wśród wielu fotografii, które Pan mi pokazuje, poznaję tylko Kondratjewa, którego spotykałam u wspólnych znajomych, małżonków Klepininów ${ }^{25}$, mieszkających w Issy-les-Moulineaux przy ulicy Madelaine Moreau, dom nr 8 lub 10. Spotykałam go dwa lata temu, gdy Kondratjew zamierzał się ożenić z Anną Suwczynską, która pracowała jako guwernantka u pani Klepininy.

Razem z mężem byliśmy zdziwieni, gdy dowiedzieliśmy się z prasy o ucieczce Kondratjewa w związku ze sprawą Reissa.

$\mathrm{Na}$ jednej z fotografii poznaję także pana Pozniakowa. Ten pan, z zawodu fotograf, powiększył dla mnie kilka fotografii. On także zna się z moim mężem, lecz niczego nie wiem o jego przekonaniach politycznych i o tym, co on teraz porabia.

Sprawa Reissa wywołała w nas z mężem tylko wzburzenie. Obydwoje potępiamy każdą przemoc, skądkolwiek by pochodziła.

Tak więc, jak Panu powiedziałam, znam tylko tych znajomych mojego męża, którzy bywali u nas $\mathrm{w}$ domu, i nie mogę powiedzieć, czy Pozniakow znał się z mademoiselle Steiner ${ }^{26}$ lub z kimkolwiek innym spośród tych, którzy zostali mi pokazani na zdjęciach.

Nie mam żadnej wiedzy o tych osobach, które Pana interesują.

24 Michaił Michajłowicz Sztrange (vel Michel Strangue; 1907-1968) - syn rosyjskich emigrantów, właściciel rosyjskiego pensjonatu-sanatorium w Górnej Sabaudii. Efronowie wraz z dziećmi spędzili tutaj lato w roku 1930 i 1936. Siergiej Efron odwiedzał to miejsce także niejednokrotnie w pojedynkę w połowie lat 40. Michaił Sztrange studiował historię i literaturę na Sorbonie, sam także zajmował się pisaniem. Do pracy agenturalnej na rzecz Kremla został zwerbowany przez Efrona. Niektórzy uważają go za koordynatora działań grupy operacyjnej, która poszukiwała Reissa. W czasie II wojny światowej należał do francuskiego ruchu oporu. Był członkiem radzieckiej wojskowej misji we Francji pod koniec wojny. W 1947 roku powrócił do ZSRR. Jak pisze Nikita Kriwoszein (1934) w korespondencji prywatnej [24 V 2017], znał Michaiła Sztrange i pamięta, jak ten już w 1945 roku paradował po Paryżu w radzieckim mundurze wojskowym. Nikita Kriwoszein uważa, że w archiwach szwajcarskich do dzisiaj znajdują się materiały dotyczące Michaiła Sztrange, lecz z powodu ich utajnienia nie ma do nich swobodnego dostępu. Z Michaiłem Sztrange wielkie nadzieje wiązała Ariadna Efron, która liczyła na uzyskanie od niego informacji z pierwszej ręki na temat działalności (w tym - agenturalnej) swojego ojca. Sztrange wielokrotnie terminy spotkań przekładał lub spotkania nagle odwoływał. W końcu nieoczekiwanie zmarł, zasmucając i rozczarowując tym samym młodą Efron. 25 Chodzi o Nikołaja Andriejewicza Klepinina (1897-1941) i jego żonę Antoninę Nikołajewną Klepinin (1892-1941) - agentów NKWD zwerbowanych przez Siergieja Efrona. Więcej o nich - zob. np. Ojcewicz, 2017.

26 Renée Steiner (1908-1986) należała do kilkuosobowej grupy szpiegowskiej, którą kierował Siergiej Efron jako agent NKWD (od 1934 roku). Urodzona w szwajcarskim Sankt Gallen. Była nauczycielką w Zurychu. Należała do Komunistycznej Partii Szwajcarii. Przed 4 IX 1937 roku dwukrotnie przebywała w Moskwie, chcąc poznać i pojąć rolę kobiet rosyjskich w życiu politycznym bolszewickiego państwa. Z sowieckimi służbami specjalnymi związała się szybko i chętnie. Wyszła nawet za mąż za niejakiego Molijenkę, agenta NKWD podstawionego jej przez ludzi Stalina. By uzyskać radziecki paszport i móc wyjechać do Moskwy i do męża, Steiner wykonywała różnorodne zadania na rzecz Kremla.W spolszczonej formie pisze się to imię najczęściej jako „Renata”. I ja przyjmuję tę postać imienia w dalszych rozważaniach. 
17 lipca 1937 roku wyjechałam z synem z Paryża do Lacanau-Océan ${ }^{27}$. Wróciliśmy do stolicy 20 września. Mąż przyjechał do nas 12 sierpnia i powrócił do Paryża 12 września 1937 roku² ${ }^{28}$.

W Lacanau zajmowaliśmy willę „Coups de Roulis” przy ulicy Braci Estrade. Ten dom należy do małżonków Cochin.

W czasie wakacji mąż cały czas był ze mną, donikąd się nie odłączał.

Tak w ogóle, mój mąż od czasu do czasu wyjeżdżał na kilka dni, lecz nigdy mi nie mówił, dokąd i po co jedzie. Ze swej strony nie żądałam od niego wyjaśnień, ściślej, nie pytałam, po prostu odpowiadał, że jedzie służbowo. Dlatego nie mogę Panu powiedzieć, gdzie on przebywał.

Po przeczytaniu potwierdzono i podpisano

Komisarz policji mobilnej (podpis)

M. Cwietajewa-Efron (podpis)

Z przypisów zamieszczonych w pracy Petera Hubera i Daniela Künziego wynika, że protokół przesłuchania Mariny Cwietajewej z 22 października 1937 roku zajął co najmniej trzy strony maszynopisu (Huber, Künzi, 1991, s. 297), jest zatem dwa razy obszerniejszy w porównaniu z kolejnym protokołem z 27 listopada 1937. Spostrzeżenie to znajduje zresztą całkowite potwierdzenie, gdy porówna się objętość obydwu wypowiedzi świadka. Warto, jak sądzę, z uwagi na wagę materiału dowodowego, zastanowić się chociażby nad kwestią prawdomówności Cwietajewej i głównych przyczynach składania miejscami... fałszywych zeznań. Czy tego typu zachowanie świadka da się wytłumaczyć tylko chęcią chronienia siebie i swojej rodziny?

Czy gdy Marina Cwietajewa zeznawała przed komisarzem Papinem, mówiąc że „Nikogo z kierownictwa tej organizacji nie znam”, nie mijała się z prawdą? Czyżby zawiodła ją wtedy pamięć o zupełnie niedawnych wydarzeniach z udziałem Twieritinowa i jego rodziny? Wypada raczej sądzić, że poetka świadomie tuszowała pewne zdarzenia z nieodległej przeszłości, licząc, być może, na to, że policja francuska nie będzie weryfikować jej zeznań. O tym, co łączyło rodzinę Efronów z rodziną Twieritinowów, najlepiej świadczy chociażby następujące wspomnienie Aleksieja Twieritinowa:

Aleksandr Aleksandrowicz [Twieritinow] lubił poezję, sam nawet kiedyś pisał wiersze, które publikowano. W „Związku Powrotu” prowadził jeszcze kółko literackie, w którym aktywnie uczestniczyła Marina Iwanowna Cwietajewa-Efron. Tutaj się poznali. Potem z mężem i maleńkim synem Murem Marina Cwietajewa gościła u Aleksandra Aleksandrowicza i jego żony Aleksandry Markowny Twieritinów. Między rodzinami zawiązały się bliskie przyjacielskie relacje. Zdarzało się, że Aleksandr odwoził Marinę na daczę Efrona swoim samochodem odddaloną ponad $70 \mathrm{~km}$ od Paryża. Nie obywało się niekiedy bez różnicy zdań. Pewnego razu Marina była w gościach u Aleksandra i ten zwrócił jej uwagę na kapitalistyczny sposób myślenia, na co ona zaprotestowała, oświadczając, że jej sposób myślenia jest prędzej „feudalny”. Potem zwymyślała Aleksandra, nazywając go bolszewikiem, obraziła się i wyszła. Po raz ostatni Aleksandr widział się z Mariną Cwietajewą w Paryżu w 1937 roku podczas przeprowadzania aresztowania

27 Dziwny zbieg okoliczności: wtedy przecież, 17 VII 1937, Ignacy Reiss został najpierw wezwany do ambasady ZSRR w Paryżu i otrzymał polecenie pilnego powrotu do kraju oraz w tę samą sobotę po wyjściu z ambasady radzieckiej przekazał trockistowskiemu „Biuletynowi Opozycji” swój otwarty list do przywódcy bolszewików w celu opublikowania i zdemaskowania m.in. agenturalnej pracy ludzi Stalina za granicą.

28 Data powrotu Efrona do Paryża, 12 IX 1937, miała sugerować śledczym, że mąż Mariny Cwietajewej nie miał nic wspólnego z zabójstwem Reissa (4 IX 1937). 
i dokonywania przeszukania przez policję paryską w jednym z towarzystw, których byli członkami. Następne spotkania odbywały się już po aresztowaniu jej męża w Rosji w podmoskiewskim Bołszewie (Тверитинов, online. Pogr. - G. O.).

Kolejną wątpliwość, gdy chodzi o prawdomówność Mariny Cwietajewej, budzą jej słowa zaczerpnięte z protokołu przesłuchania, a dotyczące Nikołaja Siergejewicza Pozniakowa: „Na jednej z fotografii poznaję także pana Pozniakowa. Ten pan, z zawodu fotograf, powiększył dla mnie kilka fotografii. On także zna się z moim mężem, lecz niczego nie wiem o jego przekonaniach politycznych i o tym, co on teraz porabia". Czyżby? Nikołaj Siergiejewicz Pozniakow (1893-1969), według Irmy Kudrowej, uczył się razem z Siergiejem Efronem w Gimnazjum Lwa Poliwanowa, w czasie I wojny światowej pracował w Międzynarodowym Czerwonym Krzyżu, a w trakcie wojny domowej aktywnie opowiedział się po stronie białych. W Paryżu miał pracownię fotograficzną. Wspólnie z Konstantinem Bolesławowiczem Rodziewiczem (1895-1988) i W. W. Janowskim "utrzymywał więzi z trockistami z POUM ${ }^{29 "}$ w czasie wojny domowej w Hiszpanii, co pozwala snuć przypuszczenia o jakimś jego udziale w rozprawie z kierownictwem POUM w 1936 roku. Kiriłł Chienkin, który znał Pozniakowa, w swojej książce Myśliwy do góry nogami (Охотник вверх ногами) wyraża się o nim skrajnie negatywnie. Po powrocie do Moskwy w 1939 roku prowadził działalność wśród byłych bojowników republikańskich. „Umarł w latach sześćdziesiątych w ojczyźnie, uniknąwszy aresztu" (Kudrowa, 1998, s. 196) - konkulduje Kudrowa.

Nieco bogatszą wiedzą na temat Nikołaja Siergiejewicza Pozniakowa dysponują zasoby Internetu. Tak na przykład dowiadujemy się z nich m.in., że był on... rosyjskim poetą i tłumaczem, znającym z gimnazjalnej ławy nie tylko Siergieja Efrona, lecz także innych twórców rosyjskich, jak Wadim Gabrielewicz Szerszeniewicz (1893-1942) czy Siergiej Wasiljewicz Szerwiński (1892-1991). Po rewolucji październikowej emigrował przez Konstantynopol i Rzym do Berlina, by w 1925 roku osiąść w Paryżu. Wspólnie z Siergiejem Michajłowiczem Prokudinem-Gorskim (1863-1944), słynnym rosyjskim fotografem, chemikiem, wynalazcą, pedagogiem i pionierem kinematografii oraz fotografii kolorowej w Rosji, założył fotoatelier „Choinka” („Елка”). W 1928 roku opublikował tomik poetycki Wiersze (Cmuxu). W jednym czasie z Efronem rozpoczął współpracę agenturalną z Moskwą ${ }^{30}$.

Ten kulturalny i oczytany człowiek otaczał się w Paryżu niewielką grupką młodych Francuzów-homoseksualistów i korzystał z ich usług obserwacyjnych na rzecz radzieckiej rezydentury. Chienkin twierdzi ponadto, że Pozniakow był „wynalazcą radykalnego sposobu walki z przeciwnikami ideowymi za granicą. Ofiarę ogłuszano, wkładano do wanny z kwasem solnym, a po pewnym czasie wszystko spuszczano do kanalizacji. Żadnych poszlak. Oszczercy, którym by przyszło do głowy twierdzić, że Moskwa zajmuje się zabójstwami politycznymi, okryliby się wstydem" ${ }^{\text {”1 }}$. Wątpliwe za-

\footnotetext{
29 W oryginale: ПОУМ. POUM z hiszp. Partido Obrero de Unificación Marxista - Robotnicza Partia Zjednoczenia Marksistowskiego.

30 https://ru.wikipedia.org/wiki/Позняков_Николай_Сергеевич (17.05.2018).

31 https://ru.wikipedia.org/wiki/Позняков_Николай_Сергеевич (17.05.2018).
} 
tem, by taka mroczna postać, jak Pozniakow była obca Cwietajewej, by nie wspominano go w rozmowach towarzyskich czy też w domowym zaciszu ${ }^{32}$.

Z kolei wiedza Mariny Cwietajewej o Wadimie Filippowiczu Kondratjewie (1903-1939?) miała się ograniczać do stwierdzenia, że spotykała go w domu Klepininów dwa lata temu, a więc w 1935 roku, i że wiadome jej były zabiegi młodego człowieka wobec guwernantki Anny Suwczynskiej, z którą zamierzał się ożenić. Klepininowie nie są tu osobami przypadkowymi, ponieważ to właśnie Nikołaj Klepinin - spokrewniony z Kondratjewem - zwerbował go do pracy agenturalnej w połowie lat 40. Rosyjski emigrant w czasie wojny domowej w Rosji walczył w szeregach Białej Armii. We Francji imał się różnych zajęć. W Paryżu pracował jako roznosiciel chleba, pomocnik zecera ${ }^{33}$, taksówkarz. Należał do paryskiego koła eurazjatów w latach 1930-1932, potem wstąpił do „Związku Powrotu do Ojczyzny” oraz Francuskiej Partii Komunistycznej. On też jako pierwszy ze specjalnej grupy operacyjnej uciekł do ZSRR po zamachu na Reissa. Pewien czas kierował jednym z południowych stalinowskich sanatoriów. Zdaniem Dmitrija Sezemana (1922-2010), tylko Kondratjew jako członek grupy ściśle związanej z zabójstwem Ignacego Reissa nie został poddany represjom, ponieważ zachorował na gruźlicę i zmarł w Moskwie. „W ten sposób prątki Kocha wygrały z NKWD” - ironizował Sezeman (zob. Соколов, online; zob. także: Прохоров, Лемехов, online).

Czy jednak tak było naprawdę? Jak zwraca słusznie uwagę Nikita Kriwoszein [list z 16 V 2018], podawany rok śmierci Kondratjewa (1939) nie musi wcale odpowiadać rzeczywistości, jeśli uwzględni się następujący zapis Gieorgija Efrona w jego Dzienniku pod datą 13 maja 1941: „Co wiem na pewno, to to, że Łarin (teraz ma zapewne inne nazwisko $)^{34}$, który był z ojcem w bardzo bliskich relacjach ${ }^{35} \mathrm{i}$ jechał $\mathrm{z}$ nim do ZSRR na jednym parostatku, przebywa na wolności w Symferopolu, tak samo, jak Kondratjew, chorujący na gruźlicę, który przyjechał do Moskwy i spotkał się z Mit'ką [Sezemanem - G. O.]. Mit'ka mówi, że on dogorywa. Kondratjew także był zmuszony uciekać z Francji w związku ze sprawą Reissa" (Эфрон, online).

Nawiązanie do Dziennika Gieorgija Efrona stanowi dobrą okazję, by przyjrzeć się bliżej wydarzeniom związanym z nagłym zniknięciem jego ojca, jak też by poznać przebieg przesłuchania w paryskiej prefekturze z punktu widzenia 12-letniego dziecka. Czy jego słowa - pisane po czterech latach - są zbieżne z wypowiedziami matki? Charakterystycznym źródłem wiedzy na dany temat jest ten sam dzień, 13 maja 1941:

\footnotetext{
32 Tę mroczność wzmacnia także wiedza o Pozniakowie przekazana przez Kiriłła Chienkina jako „żywym uchu kaponiery” (ros. наседка), czyli osobie umieszczanej przez NKWD między więźniami w celu zdobywania informacji o aresztowanych. Taką właśnie niechlubną rolę podstawionego donosiciela, agenta z celi, odegrał Pozniakow przed wybuchem II wojny światowej w jednym z nadbałtyckich obozów stalinowskich dla internowanych. W 1948 roku sam został aresztowany i wypuszczony na wolność już po śmierci Stalina. Do końca życia przeleżał sparaliżowany w szpitalu.

33 W tej samej paryskiej drukarni, której właścicielem był niejaki Borys Schwarz, pracował Nikołaj Klepinin jako administrator, Siergiej Efron zaś zajmował się korektą. Zob. np. Прянишников, 2004, s. 96.

34 Po przyjeździe otrzymał nazwisko „Klimow”.

35 Czyżby także o tych relacjach nie wiedziała Marina Cwietajewa, zeznając w paryskiej prefekturze?
} 
(...) Byłoby przecież bardzo ciekawe dowiedzieć się, czy Twiritinow ${ }^{36}$, przybyły do ZSRR po ojcu (gdy myśmy już przyjechali), znajduje się „na wolności”. Matka widziała go w Prefekturze Policji w czasie przesłuchania. (...) A w ogóle, rzecz wyglądała tak: ojciec, Lwowowie ${ }^{37}$, Łarinowie uciekli z Francji właśnie z powodu sprawy Reissa, chociaż, w rzeczy samej, ojciec nie miał z tą sprawą nic wspólnego, i w policji (Prefekturze) utwierdzili nas w przekonaniu, że ojca poszukują dokładnie nie w danej sprawie, lecz w związku ze sprawą Siedowa ${ }^{38}$. Generalny inspektor ${ }^{39}$, przesłuchujący matkę, powiedział jej, że „l’activité de votre mari était fondroyante”. Matka i ja twierdziliśmy w Prefekturze, że, jak przypuszczamy ${ }^{40}$, Efron „przebywa w Hiszpanii”, i tam nam uwierzyli4 ${ }^{41}$. Ciekawe - co z Marcelem ${ }^{42}$, którego także oskarżano o udział w przygotowaniu zabójstwa Ignacego Reissa? Ach, tak — zapomniałem o jeszcze jednym - przecież ojciec widział się w Bołszewie z jakimś Pozdniakowem ${ }^{43}$ - fotografem w Paryżu, który przybył do ZSRR po nas. Ciekawe, czy został aresztowany. 10 przyjęli pieniądze dla ojca. Wczoraj matka widziała się z Asiejewem ${ }^{44}$. Wypytywał ją o aresztowania członków naszej rodziny. Powiedział, że będzie rozmawiać w KC w sprawie wydania książki matki - że „z góry” pozwolono i jej nie wydrukowano, ponieważ $\mathrm{w}$ wydawnictwie po prostu postępowali niegodziwie, bali się - na przykład Zielinski ${ }^{45}$ odrzucił książkę. Mimo wszystko w wydanie tej książki nie wierzę. Lecz, być może, słowo Asiejewa będzie mieć swoją wagę i tę książkę wydadzą? To by było dobrze, bardzo dobrze (Эфрон, online).

Jeszcze inna wątpliwość. Marina Cwietajewa zeznaje o swoim mężu: „Od tej pory zaczął wyrażać pragnienie, by wyjechać do Hiszpanii i walczyć po stronie republikanów. Wyjechał z Vanves 11-12 października bieżącego roku i od tego czasu nie mam o nim wieści”. No właśnie! Świadek nie podaje, że Siergiej Efron wyjechał do Hiszpanii, lecz tylko zaznacza, że miał on jedynie takie pragnienie i że opuścił Vanves. Z procesowego dowodowego punktu widzenia to niezwykle istotny szczegół, zwłaszcza gdy porównamy dany fragment zeznań Cwietajewej z odpowiednim ustępem protokołu z 27 listopada 1937 roku.

Cwietajewa mówi o Efronie: „Wyjechał z Vanves 11-12 października bieżącego roku..." - to nie jest przypuszczenie, lecz konstatacja faktu. Jak rozumieć wymienienie tych dwóch dni, a nie jednego? Czy mówienie o 11/12 października oznacza, że do zniknięcia miało dojść w nocy z 11 na 12 października, z poniedziałku na wtorek, gdy Cwietajewa z Gieorgijem powrócili już z gościny u Muni Bułhakowej i zapewne

36 Powinno być „Twieritinow”.
37 Takie nowe nazwisko nosili w ZSRR Klepininowie.
38 Chodzi o Lwa Siedowa, syna Lwa Trockiego.
39 Cwietajewą 22 X 1937 roku przesłuchiwał nie generalny/naczelny inspektor, lecz komisarz policji Robert Papin, a 27 XI 1937 - naczelny inspektor Robert Borel. Przywołanie osoby naczelnego inspektora sugeruje, że Gieorgij Efron mógł mieć na myśli przesłuchanie z 27 XI 1937.

$40 \mathrm{~W}$ protokołach przesłuchań Mariny Cwietajewej zdecydowanie nie ma przypuszczenia, lecz jest suche stwierdzenie faktu.

41 Niekoniecznie uwierzyli, śledczy mógł bowiem użyć fortelu, by zmniejszyć czujność zeznających.

42 Czyli Dimitrijem Smirienskim.

43 Gieorgij Efron podobnie jak Kiriłł Chienkin zamiast „Pozniakow” pisze konsekwentnie „Pozdniakow".

44 Chodzi o rosyjskiego radzieckiego poetę, tłumacza, scenarzystę Nikołaja Asiejewa (1889-1963). W 1941 roku otrzymał Nagrodę Stalina Pierwszego Stopnia.

45 Kornelij Zielinski (1896-1970) - radziecki literaturoznawca, krytyk literacki, członek Związku Pisarzy ZSRR od 1934 roku. 
mocno spali, a Siergiej Efron wymknął się wtedy niezauważenie, dając alibi rodzinie? A może świadek, zasłaniając się niepamięcią, przytacza dwa dni, w których mogło dojść do zniknięcia? Dziwi także fakt, że nigdzie w protokole przesłuchania nie utrwalono pytania śledczego, który pragnąłby ustalić, co w tych dniach robiła sama Cwietajewa? Gdzie była? Kto może poświadczyć jej wersje zdarzeń? Dlaczego śledczy się głośno nie zastanawia nad tym, co robiła Cwietajewa przed datą zniknięcia męża i po tej dacie - jak zareagowała? Czy nie szukała go na przykład przez ambasadę radziecką? Nie pytała znajomych? Pytania szczegółowe można byłoby mnożyć. Bo to, że Cwietajewa zeznawała w paryskiej prefekturze nieprawdę na temat okoliczności „zniknięcia” Efrona, nie podlega, jak sądzę, dyskusji.

Świadek Cwietajewa podaje również do protokołu: „Nie znam nikogo wśród znajomych męża o imieniu „Bob”, nie znam także Smirienskiego ani Rollanda Marcela”. Tymczasem jej syn, Gierogij, mieszkający pod jednym dachem z matką w Vanves, w swoim Dzienniku nr 5 pod datą 5 czerwca 1940 roku odnotował:

(...) 2) Marcel (nazwiska nie znam). Widziałem go tylko we Francji, gdy zachodził do ojca. Wesoły i sympatyczny (takie odniosłem wrażenie). Był (jeśli dobrze pamiętam) na Korsyce. Po sprawie Reissa wpadł w ręce policji. Zdaje się, że go tam bili. Tutaj go nie widziałem, lecz ojciec mówił, że jest tutaj (w ZSRR). Ponieważ od dawna go nie widziałem, to niczego nie mogę o nim powiedzieć. Wrażenie pozytywne (znów na podstawie moich francuskich wspomnień) (Эфрон, online).

Prasa szybko się zorientowała w sensacyjności tematu i jego emigracyjnej nośności. Już dwa dni po przesłuchaniu Cwietajewej w paryskiej prefekturze, w niedzielnym wydaniu poczytnej i opiniotwórczej gazety emigracyjnej „Poslednije nowosti” zamieszczono artykuł podpisany inicjałami N.P.W. ${ }^{46}$, zatytułowany Zniknięcie generała Je. K. Millera. Przeszukanie w „Związku Przyjaciół Radzieckiej Ojczyzny”. Zniknięcie S. Ja. Efrona. Przestuchanie M. I. Cwietajewej w Sûreté, a w nim takie między innymi informacje:

Inspektorzy Sûreté (...) przesłuchali wszystkich znajdujących się w pomieszczeniu związku „powracających”, przeryli wszystkie książki i wydania drukiem w bibliotece oraz zabezpieczyli wszystkie papiery i dokumenty. Kilka godzin później ciężarówka załadowana opieczętowanymi paczkami odjechała na ulicę Sousse.

(...) przeszukanie w „Związku Przyjaciół Radzieckiej Ojczyzny” jest związane z dochodzeniem w sprawie zabójstwa Ignacego Reissa.

(...) W ciągu ostatnich dni w Paryżu szerzyły się pogłoski, że w ślad za tajemniczym wyjazdem N. N. i N. A. Klepininów opuścił Paryż także b. eurazjata S. Ja. Efron, który kilka lat temu

46 Pod inicjałami N. P. W. ukrywał się pracownik gazety Nikołaj Płatonowicz Wakar (1894-1970). Za tę informację dziękuję Panu doktorowi Olegowi Korostelowowi (1959), rosyjskiemu historykowi literatury, archiwiście, bibliografowi, specjaliście w dziedzinie rosyjskiej zagranicy, pracownikowi Instytutu Literatury Powszechnej im. A. M. Gorkiego Rosyjskiej Akademii Nauk. N. P. Wakar nie był jakimś przeciętnym dziennikarzem, lecz przeszedł do historii jako rosyjski działacz polityczny i społeczny, uczony filolog, sowietolog, publicysta, tłumacz i artysta. Był profesorem uniwersytetów w Bostonie i w Paryżu. 
przeszedł na radziecką platformę i wstąpił do „Związku Powrotu do Ojczyzny”. Mówiło się, jakoby Efron opuścił Francję nie sam, ale z żoną, znaną pisarką i poetką M. I. Cwietajewą.

By sprawdzić te wszystkie pogłoski, nasz pracownik pojechał wczoraj do Vanves, gdzie w ostatnim czasie mieszkali M. I. Cwietajewa i S. Ja. Efron.

M. I. Cwietajewa, jak poprzednio, przebywa w Vanves i donikąd nie wyjeżdżała.

- Około dwunastu dni temu - powiedziała nam M. I. Cwietajewa, mąż mój, pilnie się zebrawszy, opuścił nasze mieszkanie w Vanves, powiedziawszy mi, że wyjeżdża do Hiszpanii. Od tamtej pory nie mam o nim żadnych wieści. Jego radzieckie sympatie są mi znane, oczywiście, tak samo dobrze, jak i wszystkim, którzy spotykali się z mężem. Jego bliski udział we wszystkim, co dotyczyło spraw hiszpańskich (jak wiadomo, „Związek Powrotu do Ojczyzny” skierował do Hiszpanii niemałą liczbę rosyjskich ochotników), mi także był znany. Czy zajmował się on jeszcze jakąś działalnością polityczną i jaką dokładnie - nie wiem. Dwudziestego drugiego października, około godziny siódmej rano, zjawiło się u mnie czterech inspektorów policji, którzy przeprowadzili długotrwałe przeszukanie, zabrawszy z pokoju męża jego papiery i prywatną korespondencję.

Potem zostałam zaproszona do Sûreté, gdzie w ciągu wielu godzin byłam przesłuchiwana. Niczego nowego o mężu nie mogłam powiedzieć. ${ }^{47}$

Zwróćmy ponownie uwagę na szczegół związany ze zniknięciem Efrona. Tym razem w wywiadzie dla gazety „Poslednije nowosti” Marina Cwietajewa oświadcza, że jej mąż „pilnie się zebrawszy, opuścił (...) mieszkanie w Vanves, powiedziawszy (...), że wyjeżdża do Hiszpanii”. A więc jest ważna rozbieżność między tym, co świadek podał do protokołu 22 października, a tym, co powiedział dziennikarzowi dwa dni później. Czy nikt z francuskich śledczych, którzy prowadzili sprawę Reissa, nie czytał emigracyjnej prasy rosyjskiej? Nikt nie porównywał wypowiedzi świadka? Nikt nie wyciągał wniosków? Pytań jest więcej i wzmacniają je słowa żony Efrona utrwalone w kolejnym protokole przesłuchania.

\section{Protokół przesłuchania Mariny Cwietajewej z 27 listopada 1937 roku $^{48}$}

Analizowany poniżej protokół przesłuchania Mariny Cwietajewej otrzymałem dzięki uprzejmości Kseni Kriwoszeiny (1945), rosyjskiej emigrantki, na stałe mieszkającej w Paryżu, z którą współpracuję od lat, poznając życie i twórczość św. Matki Marii (Skobcowej; 1981-1945) ${ }^{49}$. Ona zaś dostała kopię tego dokumentu od znajomej

47 „Последние новости” 1937, nr 6056, 24 X, с. 1-2. Cały artykuł w wersji oryginalnej znajduje się $\mathrm{w}$ aneksie.

48 Dzień ten wypadł w sobotę, kiedy zwykle organy państwowe nie pracują, więc musiał być jakiś ważny powód, dla którego tę zasadę złamano.

49 Ksenia Igoriewna Kriwoszeina (z d. Jerszowa) urodzona 23 grudnia 1945 roku w Leningradzie rosyjska malarka, ilustratorka, publicystka. Przed emigracją do Francji (1980) należała do Związku Artystów ZSRR. Wyszła za mąż za Nikitę Kriwoszeina, syna Igora Kriwoszeina, znanego działacza francuskiego ruchu oporu, bliskiego współpracownika Matki Marii (Skobcowej) w czasie niemieckiej okupacji. Badaczka twórczości Matki Marii. Autorka strony poświęconej rosyjskiej emigrantce: www.mere-marie.com, a także książki Красота спасаю-щая - жизнь и творчество матери Маpuи. Санкт-Петербург: Издательство «Искусство-СПБ», 2004; wersja francuskojęzyczna: La beauté salvatrice. Mère Marie (Skobtsov). Peintures, dessins, broderies. Paris: Les Éditions du Cerf, 2012. 
Loïca Damilaville’a, badającego udział Mariny Cwietajewej jako świadka w sprawie zabójstwa Ignacego Reissa. Wtedy, we wrześniu 1999 roku policja francuska przekazała Damilaville’owi kserokopie dokumentów, o które prosił, co znaczy, że je wciąż przechowywała w archiwach nawet po 50 latach od tragicznego zdarzenia w Lozannie, a to $\mathrm{z}$ kolei mówi o tym, że pewne sprawy z udziałem służb specjalnych mają własne terminy deaktualizacji. Analizowany tutaj tekst był 6 i 7 stroną faksu wysłanego do Damilaville’a. To zaś podpowiada, że wśród materiałów otrzymanych przez niego mogą się znajdować również pozostałe zeznania Mariny Cwietajewej.

Analizowany protokół przesłuchania został sporządzony na dwóch kartach formatu A4 27 listopada 1937 roku, a więc prawie po trzech miesiącach od chwili zabójstwa Ignacego Reissa i po niecałych trzech miesiącach od momentu, gdy do Paryża wpłynął wniosek szwajcarskiego sędziego śledczego Trybunału Sądowego, uruchamiający międzynarodową pomoc prawną i dający podstawy do wszczęcia określonych procedur.

$\mathrm{Z}$ zapisu znajdującego się w lewej kolumnie, tuż poniżej danych o wymienionych instytucjach państwowych, wskazano numer sprawy: 70. Zaraz pod nim znalazły się nazwiska trzech oskarżonych z zaznaczeniem, że są jeszcze inne osoby w tej samej roli. Co ciekawe, zapis danych o oskarżonych nie jest do końca poprawny: o ile pierwszą z oskarżonych, która była Renèe STEINER, wymieniono z nazwiska i imienia, o tyle dwie pozostałe osoby poznajemy wyłącznie z nazwisk: SCHILDBACH ${ }^{50}$ oraz ROSSI ${ }^{51}$, co w tym miejscu nic nie mówi o płci oskarżonych; nazwiska są pisane dużymi literami, interlinia 1. W tej samej kolumnie, pod danymi o oskarżonych, jest graficzny sygnał o rozpoczęciu się zeznań świadka. Poprzedzają je podstawowe informacje o samym świadku: „Pani EFRON, urodzona TSWETAJEVA Marina, 43 lata, zamieszkała ulica Jeana-Baptisty Potina w Vanves” - bez uściślenia numeru domu.

Protokół właściwy rozpoczyna się od przywołania w pierwszym akapicie, daty przeprowadzenia czynności procesowej, przy czym wszystkie jej elementy są podawane słownie, a kolejność - od roku, przez dzień, do miesiąca: „Roku tysiąc dziewięćset trzydziestego siódmego, dwudziestego siódmego listopada ${ }^{52}$ ". Następnie, w akapicie drugim - dane o prowadzącym śledztwo, jego funkcji w danej instytucji i podległości

\footnotetext{
Autorka licznych publikacji na łamach gazety „Russkaja mysl” i wydawnictw francuskich. Inicjatorka ruchu religijnego Orthodoxie Locale de Tradition Russe oraz aktywna działaczka prawosławna we Francji.

50 Gertruda Schildbach (z d. Neugebauer) urodziła się w niemieckim Strasburgu. Żydówka. Wykształcenie wyższe humanistyczne, nauczycielka języków obcych. Po 1933 roku uciekła z Niemiec do Rzymu, gdzie była nielegalnym rezydentem NKWD. Aresztowana 1 VII 1941. Zrehabilitowana 8 X 1941; https://nekropole.info/ru/Gertruda-Shildbah (11.06.2017).

51 Rol(l)and Abbiate (alias Władimir Prawdin, ps. „Pilot”; 1904-1970) w 1937 roku był oficjalnie obywatelem Monako. Agent NKWD należący do Zarządu Zadań Specjalnych. 13 listopada 1937 roku na mocy dekretu Wszechrosyjskiego Centralnego Komitetu Wykonawczego został odznaczony orderem Czerwonego Sztandaru za ofiarne wykonanie zadań specjalnych Rządu Radzieckiego. Wtedy także otrzymał radzieckie obywatelstwo i nową tożsamość paszportową, stając się Władimirem Siergiejewiczem Prawdinem. W ZSRR dalej prowadził działalność agenturalną.

52 Kursywą wyróżniam te miejsca, które w protokole były wpisywane przez maszynistkę. Za pomoc w przetłumaczeniu protokołu dziękuję Pani Teresie Denkiewicz.
} 
służbowej względem prokuratora Republiki: „My, BOREL ${ }^{53}$ Robert naczelny inspektor policji mobilnej Wydziału Spraw Kryminalnych Inspekcji Generalnej (Generalne Biuro Bezpieczeństwa Narodowego) w Paryżu, oficer policji sądowej, pomocnik Prokuratura Republiki, (...)”. W akapicie trzecim - informacja o podstawie podjęcia czynności procesowych z przytoczeniem dat, nazwisk i instytucji zaangażowanych w sprawę o zabójstwo Ignacego Reissa: „Uwzględniając załączony niżej wniosek Sędziego Śledczego Trybunału Sądowego w Lozannie, P. Subilla, z dnia 16 września 1937 o udzielenie pomocy prawnej, przekazany nam w instrukcji z 26 tego samego miesiaca, przez Pana Doyena, sędziego śledczego Departamentu Sekwana, dotyczący procedury śledczej przeciwko STEINER Renacie, ROSSI i innym oskarżonym o zabójstwo i wspótudział w zabójstwie, (...)".

Z akapitu trzeciego wynika między innymi, że od chwili wykrycia zabójstwa (4 IX 1937) do momentu sporządzenia formalnego wniosku lozańskiego sędziego nie upłynęły nawet dwa tygodnie (16 IX 1937), co może świadczyć o sporej dynamice podjętych wtedy w Szwajcarii działań procesowych. Wniosek ten trafił następnie do Paryża, a sędzia śledczy, mający pod sobą Departament Sekwany w instrukcji z 26 września 1937 (a może 26 listopada? - w protokole jest bowiem napisane „tego samego miesiąca”, co rodzi dwuznaczność interpretacyjną) określił sposób postępowania wobec wymienionych w dokumencie dwóch oskarżonych oraz nieznanych „innych”.

W akapicie czwartym utrwalono kolejny etap postępowania przed policją francuską w związku z zabójstwem Ignacego Reissa. Czytamy w nim, że świadek został wezwany na przesłuchanie, co nie jest niczym nadzwyczajnym podczas prowadzenia wstępnych czynności procesowych, że wezwaną jest „Pani EFRON, zd. TSWETAEVA, Marina, urodzona 30 lipca 1894 roku, w Moskwie, zamieszkała przy ulicy Jeana-Baptisty Potina numer $65 w$ Vanves (Sekwana), która oświadczyła - o tym już w akapicie piątym - że „nie pozostaje $w$ stosunku pokrewieństwa ani $w$ stosunkach przyjacielskich czy pracowniczych z oskarżonymi, i złożyła przed nami przysiege, że będzie mówić cała prawdę i tylko prawdę, zeznając", co nastąpiło poniżej. Nie znamy treści owej przysięgi, nie wiemy, na co, ewentualnie, mogła przysięgać Cwietajewa - prędzej na konstytucję francuską niż na Biblię w państwie świeckim, wyraźnie oddzielonym w pewnych sprawach od wpływów Kościoła. Niewykluczone zatem, że formuła o złożeniu przysięgi wynikała z oczywistego prawa zwyczajowego i dlatego nie wymagała przytaczania źródła.

Marina Cwietajewa w swoim trzecim przesłuchaniu (a drugim w paryskiej Prefekturze Policji) zeznała, jak niżej:

Byłam już przesłuchiwana 22 października tego roku w sprawie zeznań, które składałam 21 tego samego miesiąca przed sędzią BETEILLE’M z Komisji Śledczej w Paryżu, dotyczących działalności politycznej mojego męża. Nie mam nic więcej do dodania do moich pierwszych zeznań.

53 W polskim przekładzie książki Irmy Kudrowej Tajemnica śmierci Mariny Cwietajewej tłumacz oddał to nazwisko błędnie jako „Boreille”, opierając się na fonetycznym jego zapisie w oryginale w postaci „Борель”. Podobnie w protokole francuskim imię Renaty Steiner jest utrwalone jako „Renée”, a w tłumaczeniu jako „Reneé”. I jeszcze jedna ważniejsza pomyłka: przesłuchanie w dniu 22 X 1937 roku prowadził nie komisarz Panin, lecz Papin. Zob. Kudrowa, 1998, s. 191 i 193. 


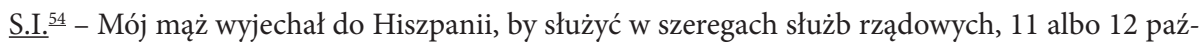
dziernika tego roku. I od tego czasu nie miałam od niego żadnych wiadomości. Wiem, że przed swoim wyjazdem do Hiszpanii, pomagał w ułatwianiu wyjazdu swoim rodakom do Hiszpańskiej Służby Rządowej, ale nie wiem, ile było tych osób. Mogę wymienić tylko dwie osoby: HENKINE, Cyrille $^{55}$ i osobę o pseudonimie Léowa (Léon) $)^{56}$.

S.I. - Potwierdzam, że nic nie wiedziałam o tym, że mój mąż w roku 1936 i na początku roku 1937 zajmował się wywiadem obserwacyjnym na rzecz Rosji przy współudziale Pani STEINER Renaty, SMIRIENSKIEGO Dimitrija, TCHISTOGANOFFA ${ }^{57}$ i DUCOMETA ${ }^{58}$ Pierre'a. Nic mi również nie wiadomo, czy mój mąż prowadził z nimi korespondencję.

S.I. - Nie podejmuję się określenia, czy rzeczywiście tekst telegramu z dnia 22 stycznia 1937 roku widoczny na fotokopii, która została mi pokazana, jest napisany ręką mojego męża.

Na pańską prośbę składam do zarejestrowania dziewięć dokumentów pisanych ręką mojego męża (listy, koperty i jedna kartka pocztowa).

Odczytano, potwierdzono i podpisano.

M. Zvétaïeff-Efron

Naczelny Inspektor Policji Mobilnej

Oficer Policji Sądowej.

54 Pod dwiema literami „S.I.” kryje się francuskie „sur interpellation”, a więc sygnał słowny, że na „zadane pytanie świadek odpowiedział”.

55 Kiriłł Wiktorowicz Chienkin (Кирилл Викторович Хенкин; 1916-2008 Monachium) był rosyjskim pisarzem emigracyjnym, dziennikarzem i tłumaczem. Wywieziony z Rosji przez rodziców w 1923 roku. Należał do grona osób zwerbowanych przez Siergieja Efrona do walki w wojnie domowej w Hiszpanii, by wspierać republikanów. Z wyboru lub życiowej konieczności stał się agentem INO NKWD, czyli do Zagranicznego Wydziału Wywiadu Politycznego Głównego Zarządu Bezpieczeństwa Państwowego (INO NKWD). Z racji wykonywanej misji agenturalnej znał się z rezydentem INO NKWD w Hiszpanii, Aleksandrem Orłowem. Jego działalnością interesował się do końca swojego życia. Powróciwszy z Hiszpanii do Francji, Chienkin wstąpił na Uniwersytet Paryski i ukończył kierunek „literaturoznawstwo porównawcze”. W 1941 roku powrócił do ZSRR. Podjął służbę w jednym z zarządów NKWD, potem w moskiewskim radiu na zagranicę, a jeszcze później - w redakcji czasopisma „Problemy mira i socjalizma”. Opuścił Związek Radziecki w latach 80. XX wieku. Pracował w radiu „Swoboda”. Autor kilku książek opartych na własnej biografii. Swego czasu Loïc Damilaville przyjaźnił się z Kiriłłem Chienkinem, który zapewne dysponował wiarygodnymi informacjami na temat zabójstwa Reissa.

56 Lew Borisowicz Sawinkow (Лев Борисович Савинков, 1912-1987) - rosyjski emigracyjny dziennikarz, poeta, prozaik, syn Borisa Sawinkowa, znanego działacza partii eserowców i pisarza. Żył we Francji i tam został pochowany na podparyskim cmentarzu prawosławnym w Sainte-Genevièvedes-Bois. Od 1936 roku przez półtora roku walczył, podobnie jak Chienkin, w wojnie domowej w Hiszpanii po stronie armii republikańskiej, zasilając brygadę międzynarodową. Został ciężko ranny. Potem zachorował na gruźlicę. Do pracy agenturalnej zwerbował go Siergiej Efron w 1937 roku. Przyjaźnił się z Ariadną Efron, która jeszcze przez kilka lat po opuszczeniu Francji prowadziła z nim korespondencję. W czasie II wojny światowej trafił do francuskich partyzantów i walczył z niemieckim okupantem.

57 Anatolij Czistoganow (Анатолий Чистоганов / TCHISTOGANOFF, 1910-194?) - emigrant rosyjski, uczestnik ruchu białych. Członek „Związku Powrotu do Ojczyzny”. Zwerbowany do stalinowskich służb agenturalnych. Brał udział w śledzeniu Lwa Siedowa.

58 Pisownia błędna. Powinno być: DUCOMMETA. 
Uściślamy, że dziewięć dokumentów przekazanych nam przez Panią EFRON zostało dokładnie zabezpieczonych. Pani EFRON wspólnie z nami złożyła swój podpis na zabezpieczonych dokumentach.

Naczelny Inspektor Policji Mobilnej Oficer Policji Sądowej.

Z przytoczonych wypowiedzi Mariny Cwietajewej płyną określone spostrzeżenia i wnioski:

1. że przed 27 listopada 1937 roku była przesłuchiwana dwukrotnie w związku z działalnością polityczną Siergieja Efrona we Francji i sprawą o zabójstwo Ignacego Reissa: najpierw 21 października 1937 stawiła się przed sędzią BETEILLE z paryskiej Komisji Prawnej, a dzień później, 22 października 1937 roku, zeznawała przed komisarzem Robertem Papinem z lokalnej policji mobilnej;

2. że 22 października 1937 roku złożyła najobszerniejsze zeznania, które nie wniosły do sprawy zabójstwa Ignacego Reissa żadnych istotnych informacji;

3. że świadek zmieniał miejscami swoje zeznania, lecz fakt ten umknął uwagi oficerowi prowadzącemu śledztwo (zob. np.: „Od tej pory zaczął wyrażać pragnienie, by wyjechać do Hiszpanii i walczyć po stronie republikanów. Wyjechał z Vanves 11-12 października bieżącego roku i od tego czasu nie mam o nim wieści” w protokole z 22 października 1937 i „Mój mąż wyjechał do Hiszpanii, by służyć w szeregach służb rządowych, 11 albo 12 października tego roku” - w protokole z 27 listopada 1937);

4. że nie dysponujemy pytaniami zadawanymi przez przesłuchujących, ponieważ nie zostały zawarte w protokołach przesłuchań;

5. że jesteśmy w stanie domyślić się tylko pytań stawianych przez przesłuchującego podczas drugiego i trzeciego przesłuchania świadka, na które znajdujemy odpowiedzi w samych protokołach.

Tak więc, w odniesieniu do akapitu drugiego zeznań Cwietajewej z 27 listopada 1937 roku, przesłuchujący mógł postawić takie przykładowo pytania :

1. Gdzie obecnie znajduje się Pani mąż ? „S.I. - Mój mąż wyjechał do Hiszpanii”...).

2. W jakim celu udał się Pani mąż do Hiszpanii („...by służyć w szeregach służb rządowych”.).

3. Kiedy Pani mąż wyjechał do Hiszpanii? („11 albo 12 października tego roku [1937 - GO]".

4. Czy od tamtego czasu Siergiej Efron kontaktował się z Panią? („I od tego czasu nie miałam od niego żadnych wiadomości”.).

5. A czy wiadomo Pani, czym się zajmował Pani mąż przed wyjazdem do Hiszpanii? („Wiem, że przed swoim wyjazdem do Hiszpanii, pomagał w ułatwianiu wyjazdu swoim rodakom do Hiszpańskiej Służby Rządowej”).

6. A czy wie Pani, ilu osobom pomógł Siergiej Efron w ramach tej działalności? („ale nie wiem, ile było tych osób”).

7. Czy jest Pani w stanie podać nazwiska tych osób? („Mogę wymienić tylko dwie osoby: HENKINE, Cyrille i osobę o pseudonimie Léowa [Léon]”).

8. A czy wiadomo Pani, że w 1936 roku i na początku 1937 Siergiej Efron zajmował się wywiadem obserwacyjnym na rzecz Rosji i że pomagały mu w tych czynnościach takie osoby, jak STEINER Renata, SMIRIENSKI Dimitrij, TCHISTOGA- 
NOFF i DUCOMET Pierre? („S.I. - Potwierdzam, że nic nie wiedziałam o tym, że mój mąż w roku 1936 i na początku roku 1937 zajmował się wywiadem obserwacyjnym na rzecz Rosji przy współudziale Pani STEINER Renaty, SMIRIENSKIEGO Dimitrija, TCHISTOGANOFFA i DUCOMETA Pierre'a”).

9. A czy wiadomo Pani, czy Siergiej Efron prowadził korespondencję z tymi osobami? („Nic mi również nie wiadomo, czy mój mąż prowadził z nimi korespondencję").

10. Czy bierze Pani na siebie odpowiedzialność za identyfikację kserokopii telegramu z datą 22 stycznia 1937 roku, która Pani okazano, i czy jest Pani w stanie stwierdzić, czy ten telegram został napisany przez Pani męża? („S.I. - Nie podejmuję się określenia, czy rzeczywiście tekst telegramu z dnia 22 stycznia 1937 roku na fotokopii, która została mi pokazana, jest napisany ręką mojego męża”.).

Dalej, prawdopodobnie na wniosek samego świadka, umieszczono w protokole przesłuchania uściślenie o dostarczeniu przez Marinę Cwietajewą dziewięciu różnych dokumentów, sporządzonych ręką Siergieja Efrona, jak wybrane (przez Cwietajewą!) listy, koperty i kartka pocztowa, o które poprosiła policja francuska, w celu ich zarejestrowania do, najpewniej, dalszych badań grafologicznych.

Gdy przeanalizujemy zeznania Mariny Cwietajewej pod kątem biografii jej własnej i członków rodziny, rodzi się ważne pytanie, czy rzeczywiście w paryskiej Prefekturze Policji składała dwukrotnie zeznania... Marina Cwietajewa. Czy francuscy policjanci sprawdzili tożsamość przesłuchiwanej osoby? Czy sięgnęli do danych zawartych w paszporcie świadka? Tę tak istotną wątpliwość formalną uzasadniają rażące błędy, które zachowały się w obydwu protokołach przesłuchania świadka i które dowodzą jednoznacznie, że świadek poświadczył nieprawdę. Mniejsza nawet o błąd, polegający na podaniu niewłaściwego roku przybycia Efronów do Francji: zamiast 1925 - 1926, myślę bowiem przede wszystkim o wymienieniu przez świadka dwóch różnych dat urodzin i utrwaleniu ich w dokumentach, mianowicie w protokole z 22 października 1937 Cwietajewa zeznaje, potwierdza i podpisuje, że urodziła się 31 lipca 1894 roku, a w protokole z 27 listopada podaje, że do jej narodzin doszło 30 lipca 1894 roku. W rzeczy samej ta wybitna pisarka przyszła na świat 26 września 1892 roku (według nowego stylu: 8 października), a jej rodzicami byli moskwianie - profesor Uniwersytetu Moskiewskiego Iwan Władimirowicz Cwietajew (1847-1913) oraz pianistka Maria A. Meyn (1868-1906), nie zaś, jak to zostało zapisane w protokole z 22 października 1937 roku - Iwan i Maria Bernscy. Dalej: Marina Cwietajewa zeznaje, potwierdza i podpisuje zeznanie, z którego ma wynikać, że jej rodzona córka, Ariadna Efron, urodziła się 5 września 1913 roku, gdy tymczasem fakt ten miał miejsce w 1912 roku. Zapytajmy: czyżby stan emocjonalny świadka był na tyle zły, że Marina Cwietajewa nie kontrolowała w pełni tego, co zeznawała, następnie potwierdzała i na końcu podpisywała? Przecież musiała mieć przynajmniej podstawową świadomość, że za składanie fałszywych zeznań grożą jej określone sankcje karne i że podpisując protokół zawierający nieprawdziwe dane, sprowadza na siebie potencjalne niebezpieczeństwo procesowe. Dlaczego Marina Cwietajewa dwukrotnie podała do protokołu przesłuchania świadka błędne informacje? Odstęp w czasie między 22 października a 27 listopada 1937 roku jest raczej wystarczający, by ostudzić emocje i na trzeźwo podejść do nowego przesłuchania. Zapytajmy następnie: czy Robert Borel znał treść 
protokołu przesłuchania z 22 października, które prowadził jego kolega, Robert Papin? Czy protokół Papina nie znajdował się w teczce dotyczącej zabójstwa Ignacego Reissa? Czy Borel nie porównywał następnie dwóch protokołów ze sobą? Wychodzi na to, że nie, ponieważ nie mamy dalszych śladów dokumentacyjnych, z których by wynikało, że świadek prostował wcześniejsze zeznania. Są to zarazem poboczne informacje o sposobach i jakości pracy ówczesnych francuskich organów śledczych. Czy fakt, że były to niejako czynności dodatkowe, zlecone przez organ szwajcarski, a nie lokalny, mógł usprawiedliwiać zawodową niezbyt wysoką staranność formalną francuskich śledczych?

\section{Biorytmika jako źródło interpretacji zdarzeń}

Czy określoną winę za kształt zeznań Mariny Cwietajewej w odniesieniu do pomyłek faktograficznych może ponosić jej niekorzystna kondycja fizyczno-psychiczno-intelektualna? Wydaje się, że w jakimś stopniu na pewno tak, co ma czytelne odniesienie przede wszystkim do jej zeznań z 22 października 1937 roku. O biorytmice jako metodzie śledczej oraz praktycznym jej wykorzystaniu w rozwiązywaniu intrygujących kwestii badawczych pisałem już wcześniej (zob. Ojcewicz, 2016, s. 347-372). Dziś chcę zastosować tę metodę w sprawie Mariny Cwietajewej.

Jak wyglądała Marina Cwietajewa jesienią 1937 roku? Jak się czuła? Czy można było po niej poznać, że przeżywa jakiś wewnętrzny dramat? Odpowiedź ponownie jest twierdząca, a dowodów dostarczają spostrzeżenia naocznych świadków. Wspomniany wcześniej Mark Słonim tak ją wtedy postrzegał: „wychudła, postarzała się, zmęczona, uosabiała nieustającą zgryzotę, mówiła, że chciałaby umrzeć, lecz musi żyć dla syna; mężowi i córce nie jest już więcej potrzebna. I jeszcze o tym, że będzie musiała opuścić mieszkanie: zatrują życie emigranci; i że trzeba iść do „Związku Powrotu” i do radzieckiego konsulatu. Że drukować jej teraz nie będą...” (Саакянц, 2002, s. 718. Pogr. - G. O.). Podobnie - Nina Berberowa (1901-1993), oceniła zły stan psychiczny poetki, gdy widziała ją 31 października 1937 roku stojącą, zapłakaną i jakby przez wszystkich odepchniętą przed paryskim kościołem w trakcie mszy żałobnej w intencji zmarłego w Stanach Zjednoczonych emigranta Siergieja Michajłowicza Wołkonskiego (1860--1937) - rosyjskiego działacza teatralnego, reżysera, krytyka memuarysty, literata, radcy stanu, szambelana. W znakomitej książce Niny Berberowej Podkreślenia mоје (Курсив мой) autorka ta napisała (Berberowa, 1998, s. 392):

M. I. Cwietajewą widziałam po raz ostatni na pogrzebie (albo nabożeństwie żałobnym) księcia Siergieja Wołkonskiego, 31 października 1937 roku. Po nabożeństwie w cerkwi przy ulicy François-Gérard (Wołkonski był katolikiem wschodniego obrządku) wyszłam na ulicę. Cwietajewa stała samotnie na trotuarze i patrzyła na nas oczami pełnymi łez; postarzała się, była niemal zupełnie siwa, stała z gołą głową i skrzyżowanymi na piersi rękami. Było to wkrótce po zamordowaniu Ignacego Reissa, a w zabójstwo to był zamieszany jej mąż, S. J. Efron. Stała jak zadżumiona, nikt do niej nie podszedł. Ja minęłam ją tak jak wszyscy (Pogr. - G. O.).

A ona sama w liście do Ariadny Berg z 26 października 1937 roku mówi, że „więcej pisać nie mogę, ponieważ jestem całkiem przybita z powodu wydarzeń, które także są nieszczęściem, a nie winą". Pytam więc, jakie były biorytmy - fizyczny, psychiczny 
i intelektualny - Mariny Cwietajewej w dniach 22 X 1937 i 27 listopada 1937 roku i czy mogły one wpłynąć na przebieg przesłuchania, na odpowiedzi świadka?

Tabela 1. Biorytmy Mariny Cwietajewej w październiku 1937 roku liczone według kalendarza juliańskiego (data urodzin 26 IX 1892).

\begin{tabular}{|c|c|c|c|c|c|c|c|c|c|c|c|c|c|c|c|c|c|c|c|c|c|c|c|c|c|c|c|c|c|c|c|}
\hline & 1 & 2 & 3 & 4 & 5 & 6 & 7 & 8 & 9 & 10 & 11 & 12 & 13 & 14 & 15 & 16 & 17 & 18 & 19 & 20 & 21 & 22 & 23 & 24 & 25 & 26 & 27 & 28 & 29 & 30 & 31 \\
\hline $\mathrm{F}$ & - & - & - & - & 0 & 0 & + & + & + & + & + & + & + & + & + & + & $\mathrm{X}$ & - & - & - & - & - & - & - & - & - & - & 0 & 0 & + & + \\
\hline $\mathrm{P}$ & + & + & + & + & + & + & + & + & + & + & + & $\mathrm{X}$ & $\mathrm{X}$ & - & - & - & - & - & - & - & - & - & - & - & - & 0 & 0 & + & + & + & + \\
\hline $\mathrm{I}$ & + & + & + & + & + & + & + & + & + & + & $\mathrm{X}$ & - & - & - & - & - & - & - & - & - & - & - & - & - & - & - & 0 & 0 & + & + & + \\
\hline
\end{tabular}

Gdzie tu i dalej:
F - cykl biorytmu fizycznego
P - cykl biorytmu psychicznego
+ wyż cyklu
I - cykl biorytmu intelektualnego
- niż cyklu
0 dzień zerowy
$\mathbf{X}$ dzień krytyczny

Jak widać, 22 października 1937 roku wszystkie biorytmy w organizmie Mariny Cwietajewej przyjęły wartości ujemne: biorytm fizyczny osiągnął swe najniższe położenie - depresję, minusowy biorytm psychiczny miał tendencję wzrostową, podobnie jak minusowy biorytm intelektualny. Taki układ biorytmów skutkował najprawdopodobniej spóźnionymi reakcjami świadka, sprawiał trudności związane z zebraniem i uporządkowaniem myśli, mógł wywoływać nie tylko szybkie zmęczenie sensoryczne, lecz także łatwo doprowadzać do irytacji. W takim bardzo niekorzystnym układzie biorytmicznym wszystko w organizmie, jeśli nie „śpi”, to pracuje na bardzo zwolnionych obrotach. Cwietajewa musiała się zatem wtedy mocno pilnować, aby nie powiedzieć czegoś, co mogłoby zaszkodzić Siergiejowi Efronowi, jej samej i ich synowi.

Tabela 2. Biorytmy Mariny Cwietajewej w listopadzie 1937 roku liczone według kalendarza juliańskiego (data urodzin 26 IX 1892).

\begin{tabular}{|l|l|l|l|l|l|l|l|l|l|l|l|l|l|l|l|l|l|l|l|l|l|l|l|l|l|l|l|l|l|l|}
\hline & 1 & 2 & 3 & 4 & 5 & 6 & 7 & 8 & 9 & 10 & 11 & 12 & 13 & 14 & 15 & 16 & 17 & 18 & 19 & 20 & 21 & 22 & 23 & 24 & 25 & 26 & 27 & 28 & 29 & 30 \\
\hline $\mathrm{F}$ & + & + & + & + & + & + & + & + & $\mathrm{X}$ & - & - & - & - & - & - & - & - & - & - & 0 & 0 & + & + & + & + & + & + & + & + & + \\
\hline $\mathrm{P}$ & + & + & + & + & + & + & $\mathrm{X}$ & $\mathrm{X}$ & - & - & - & - & - & - & - & - & - & - & - & - & 0 & 0 & + & + & + & + & + & + & + & + \\
\hline $\mathrm{I}$ & + & + & + & + & + & + & + & + & + & + & + & + & $\mathrm{X}$ & - & - & - & - & - & - & - & - & - & - & - & - & - & - & - & 0 & 0 \\
\hline
\end{tabular}

Z kolei przebieg cyklów Mariny Cwietajewej w dniu 27 listopada 1937 jest dość korzystny: biorytm fizyczny dodatni, zaledwie dwa dni temu był szczyt wyżu, biorytm psychiczny - również dodatni i zbliżał się do najwyższej wartości, a także biorytm intelektualny, mimo że ujemny, miał tendencję wzrostową i biegł do punktu zerowego, przejściowego. Takie rozłożenie wartości biorytmów skutkuje na ogół dość dobrym samopoczuciem osoby, pewnością siebie, większą otwartością na trudne kwestie i zajmowaniem zdecydowanego stanowiska w określonej sprawie. Objętość protokołu przesłuchania Cwietajewej w danym dniu przekonuje, że było ono raczej krótkie i rzeczowe: odpowiedzi jasne, co nie znaczy, że za każdym razem prawdziwe. 
Na marginesie, z badawczej ciekawości proponuję przyjrzeć się jeszcze biorytmom poetki w tragicznym dla niej dniu 31 sierpnia 1941 roku, gdy Cwietajewa popełniła samobójstwo:

Tabela 3. Biorytmy Mariny Cwietajewej w sierpniu 1941 roku liczone według kalendarza juliańskiego (data urodzin 26 IX 1892).

\begin{tabular}{|l|l|l|l|l|l|l|l|l|l|l|l|l|l|l|l|l|l|l|l|l|l|l|l|l|l|l|l|l|l|l|l|}
\hline & 1 & 2 & 3 & 4 & 5 & 6 & 7 & 8 & 9 & 10 & 11 & 12 & 13 & 14 & 15 & 16 & 17 & 18 & 19 & 20 & 21 & 22 & 23 & 24 & 25 & 26 & 27 & 28 & 29 & 30 & 31 \\
\hline $\mathrm{F}$ & - & - & - & - & - & - & - & 0 & 0 & + & + & + & + & + & + & + & + & + & + & $\mathrm{X}$ & - & - & - & - & - & - & - & - & - & - & 0 \\
\hline $\mathrm{P}$ & + & + & + & + & + & + & + & + & + & $\mathrm{X}$ & $\mathrm{X}$ & - & - & - & - & - & - & - & - & - & - & - & - & 0 & 0 & + & + & + & + & + & + \\
\hline $\mathrm{I}$ & - & - & - & - & - & - & - & - & - & - & - & - & 0 & 0 & + & + & + & + & + & + & - & - & - & 0 & & + & + & + & + & + & + \\
\hline
\end{tabular}

Muszę przyznać, że układ cyklów Mariny Cwietajewej w danym dniu nie jest typowy dla samobójców: punkt zerowy w biorytmie fizycznym po przebiegu wartości ujemnych, dodatni biorytm psychiczny zbliżający się do szczytu wyżu, pierwszy dzień minusowy w biorytmie intelektualnym po przejściu przez moment krytyczny. Wydaje się, że przy takim układzie biorytmów, w dniu zaplanowanej śmierci intelekt (zaraz po dniu krytycznym) nie był w stanie zapanować nad gwałtownością ciała (punkt zero w biorytmie fizycznym, przewaga reakcji nad rozumem); psychika mówiła „zrób to”, siła fizyczna pozwalała na podjęcie zabójczego działania, a intelekt trwał w uśpieniu... Skutek tych okoliczności znamy.

Gdy zestawimy ponadto jednozdaniowe pismo Mariny Cwietajewej z 26 sierpnia 1941 roku (na 5 dni przed samobójstwem) do kierownictwa nowo otwartej stołówki Litfondu (ryc. 5 w aneksie), w którym prosi ona o posadę... pomywaczki (!), z ostatnim przedśmiertnym i pożegnalnym zarazem listem poetki do syna Gieorgija z 31 sierpnia 1941, z łatwością dostrzeżemy, jak wielka, a w skutkach zabójcza, rana psychiczna została uczyniona w ciągu zaledwie kilku dni. Prośbę swą z 26 sierpnia pisała poetka $\mathrm{w}$ wyżach psychicznym i intelektualnym, a więc jakaś nadzieja na wyjście z upodlenia jeszcze w Cwietajewej mogła żyć, o czym obiektywnie świadczy grafika: równe pismo, kształtne litery, utrzymanie się równoległych wersów, chociaż z tendencją wyraźnie spadkową na końcach, co sygnalizowało utrzymywanie się od dłuższego czasu depresji. Pewną ręką nakreślony podpis, poprawna data. Zaprzeczenie tego pozornego tylko spokoju odnajduję w notatce do syna: tutaj wszystko rozpaczliwie łka: litery są nierówne, biegnące w prawo w dół wersy potwierdzają załamanie psychiczne piszącej, nierówne odstępy pomiędzy poszczególnymi wersami to ślady oddechów pomiędzy kolejnymi wybuchami szlochu, a charakterystyczne drżenie ręki czy może nawet całego ciała utrwaliło się w zapisie litery „ż” (ж) w słowie „żyć” (жить). Dzień tragicznej śmierci poetki oznaczał zarazem kres ludzkiej wytrzymałości: w jednym miejscu i czasie personifikowane przez Marinę Cwietajewą intelektualne wyżyny kultury i estetyki europejskiej sromotnie przegrały z bolszewickim prostactwem i stalinowskim okrucieństwem. Czy jednak ta Kometa całkowicie zmitrężyła swój szlak i blask? 


\section{Wnioski i zakończenie}

1. Protokół przesłuchania Mariny Cwietajewej z dnia 22 października 1937 roku jest dwa razy obszerniejszy od protokołu przesłuchania z dnia 27 listopada 1937 roku, co świadczy o tym, że zasadniczy materiał dowodowy śledczy zebrał za pierwszym razem, a za następnym uściślano lub aktualizowano kwestie, które były istotne dla procesu w danym czasie.

2. Marina Cwietajewa była bardziej świadkiem w sprawie działalności politycznej własnego męża, aniżeli w związku ze skrytobójczą śmiercią Ignacego Reissa. Dlatego jej zeznania nie wniosły niczego istotnego do sprawy o zabójstwo radzieckiego agenta.

3. Marina Cwietajewa jako świadek nie była osobą zbyt wiarygodną głównie z uwagi na podpisywanie i potwierdzanie zeznań, w których występowały istotne błędy, zwłaszcza natury faktograficznej oraz biograficznej, dotyczące jej samej i członków jej rodziny.

4. W zeznaniach Mariny Cwietajewej wyczuwa się wewnętrzną dyscyplinę i obawę przed powiedzeniem czegokolwiek, co mogłoby zaszkodzić bezpośrednio Siergiejowi Efronowi, a w dalszej kolejności jej samej i synowi.

5. Analiza biorytmów Mariny Cwietajewej na dzień 22 października 1937 roku przekonuje, że zarówno biorytm fizyczny, psychiczny i intelektualny stworzyły niekorzystną konfigurację, która uzasadniałaby złe samopoczucie świadka i brak pełnej koncentracji podczas składania zeznań, a w konsekwencji - pomyłki i ich usankcjonowanie przez podpisanie protokołu jako zgodnego ze stanem faktycznym.

6. Marina Cwietajewa podczas przesłuchań w paryskiej prefekturze, a także udzielając wywiadu do gazety „Poslednije nowosti” z lepszym lub gorszym skutkiem odegrała określoną rolę, do której przygotowała się sama i swego nieletniego syna.

Perfidia NKWD - jej wyrachowanie, podłość, lubowanie się w upodleniu człowieka, cynizm, agresywność, arogancja i wiele innych jeszcze bardzo negatywnych charakterystyk stalinowskiej Łubianki - nie dopadła Cwietajewej dopiero w ZSRR. Można chyba niebezpodstawnie założyć, że Siergiej Efron jeszcze we Francji w jakiś delikatny sposób sugerował żonie, by przeszła na stronę bolszewików i wspomogła swoim wielkim talentem sowiecką agenturę. Pozyskanie kogoś takiego, jak Cwietajewa, musiałoby być nie tylko zauważone przez Moskwę, lecz także odpowiednio docenione i wysoko nagrodzone. Ułatwić mogło także znacznie szybsze otrzymanie zgody na powrót do ZSRR. Dowodów w tej niezwykle drażliwej małżeńskiej sprawie na pewno nie ma. Lecz jest pewna poszlaka, która wskazuje na potencjalną aktywność NKWD w danej sferze. Przecież nawet w Jełabudze, na ostatnim etapie upodlenia poetki, pracownicy NKWD zarzucali na nią swoje śmiercionośne sieci, proponując współpracę ze służbami specjalnymi. Tego typu poniżająca godność osobistą pisarki oferta nie tylko boleśnie dotknęła nadwrażliwą Cwietajewą, lecz ją najzwyczajniej w świecie psychicznie zabiła, i, niewykluczone, że ostatecznie przyspieszyła decyzję o całkowitym wyzwoleniu się z macek systemu przez popełnienie samobójstwa. Przeanalizowane protokoły oraz przyjrzenie się fragmentowi emigracyjnej paryskiej rzeczywistości rosyjskich emigrantów, uwikłanych przez złą historię w złe sprawy, rzuca, jak sądzę, dodatkowe, 
chociaż ponure, światło na ludzi i czasy, w których jedni naiwnie ufali w uczciwość Kremla, a drudzy masowo ginęli z rozkazów moskiewskiego szaleńca.

\section{Bibliografia}

Berberowa, N. (1998). Podkreślenia moje. Autobiografia. Przeł. E. Siemaszkiewicz. Warszawa: Noir sur blanc.

Duff, W. E. (1999). A Time for Spies: Theodore Stepanovich Mally and The Era of The Great Illegals. Nashville and London: Vanderbilt University Press.

Huber, P., D. Künzi (1991). Paris dans les années 30: Sur Serge Efron et quelques agents du NKVD. W: Cahiers du Monde Russe et Soviétique. Vol. 32 (2), avril-juin, s. 285-310.

Janczuk, E. (2013). Język poetycki Mariny Cwietajewej. Warszawa: Uniwersytet Warszawski (ebook, PDF).

Kudrowa, I. (1998). Tajemnica śmierci Mariny Cwietajewej. Tłum. i posł. K. Tur. Białystok: Wydawnictwo „Łuk”.

Maciejewski, Z. (1982). Proza Maryny Cwietajewej jako program i portret artysty, Warszawa: Państwowe Wydawnictwo Naukowe.

Majmieskułow, А. (1992). Провода под тирическим током. Цикл Марины Цветаевой «Провоda», Bydgoszcz: Wydawnictwo Uczelniane WSP.

Ojcewicz, G. (2016). Biorytmika jako źródło interpretacji zdarzeń. W: Myślak, D. A. Ojcewicz, G. (red.). Stara Dusza. Fenomen Matki Marii (Skobcowej). Badania i materiały. Szczytno: Wydawnictwo „GregArt”, s. 347-372.

Ojcewicz, G. (2017). Z filologii śledczej. Praca agenturalna stalinowskich służb specjalnych za granicą na przykładzie sprawy o zabójstwo Ignacego Reissa. Studia Rossica Gedanensia, t. 4, s. 297-332.

Piwkowska, A. (2017). Wyklęta. Poezja i miłość Mariny Cwietajewej. Warszawa: Iskry.

Pollak, S. (1968). Wstęp. W: Cwietajewa, M. Poezje. Warszawa: Państwowy Instytut Wydawniczy.

Poretsky, E. K. Léon Trotsky (1969). Les Nôtres: vie et mort d’un agent soviétique (Our own people). Tłum. O. Simon. Paris: Denoël, Les Lettres nouvelles.

Poretsky, E. K. (1969). Our Own People: A Memoir of "Ignace Reiss" and His Friends. London: Oxford University Press.

Raetz, E. (2006). Hôtel de la Paix. Ein politischer Mord in Lausanne. Bretten: INFO Verlag.

Reiss, E. (1938). Ignace Reiss: In Memoriam. New International. (September), s. 276-278.

Sudopłatow, P. (1999). Wspomnienia niewygodnego świadka. Tłum. J. Markowski. Warszawa: Dom Wydawniczy Bellona.

Вейхман, В. (2008). Каждый день я прихожу на пристань. Урал, № 7. Online: https://proza. $\mathrm{ru} / 2009 / 10 / 31 / 512(31.05 .2017)$.

Каган, Ю. М. (1992). Марина Цветаева в Москве. Путь к гибели. Москва: Отечество.

Клот, Л. Знакомые лица: романдиы века на наших страницах | Le général Guisan élu Romand du siècle. Online: http://nashagazeta.ch/news/12648 (1.06.2017).

Клот, Л. Игнатий Рейсс: загадочная смерть советского шпиона под Лозанной | Ignace Reiss, mort d’un espion soviétique à Lausanne. Online: http://nashagazeta.ch/news/14121 (20.05.2017).

Кривошеина, К. (2016). Неэвклидов палиндром имен и судеб, небесных и не очень. Online: http:// mere-marie.com/life/neevklidov-palindrom-imen-i-sudeb/ (22.10.2016); Новый журнал, № 10. Online: http://newreviewinc.com/kseniya_krivosheina/ (18.10.2016).

Кудрова, И. (1997). Гибель Марины Цветаевой. Москва: Независимая Газета.

Кудрова, И. (2002). Жизнь Марины Цветаевой: документальное повествование. Звезда.

Кудрова, И. (2016). Марина Цветаева: беззаконная комета Ирма Кудрова Биограбии и мемуapbl. Москва: Издательство: АСТ. 
Кудрова, И. (2002). Путь комет. Жизнь Марины Цветаевой. Москва: Вита Нова.

Лебедев, В. (1997). Пераст (Perast). Пер. на фр. М. Цветаева. Москва: Дом-музей Марины Цветаевой.

Лосская, В. (1992). Марина Цветаева в жизни: неизданные воспоминания современников). Москва: Культура и традиции; Дом Марины Цветаевой.

Порецкая, Е. К. (1992). Наши. Воспоминания об Игнатии Райссе и его товарищах. Москва: Издательство ВДА. Online: http://militera.lib.ru/memo/russian/poretskya_ek/index.html (17.06.2017).

Прохоров, Д. П., Лемехов, О. И. Перебежчики. Заочно расстреляны. Online: http://coollib. $\mathrm{com} / \mathrm{b} / 271956 / \mathrm{read}(17.06 .2017)$.

Прянишников, Б. (2004). Незримая паутина: ОГПУ-НКВД против белой эмиграции. Москва: Яуза-Эксмо.

Роговин, В. 3. (1996). Прозрение и гибель Игнатия Райса. В: Роговин, В. 3. 1937. Москва: (brak danych o wydawnictwie). Online: http://www.litres.ru (wersja PDF) (dostęp: 11 VI 2017) .

Роговин, В. 3. (1996). Прозрение и гибель Игнатия Райса. В: Роговин, В. 3. 1937. Москва: (brak danych o wydawnictwie).

Саакянц, А. (2002). Жизнь Цветаевой. Бессмертная птица-феникс. Москва: Центрполиграф.

Соколов, М. Дмитрий Сеземан: Марина Цветаева, Георгий Эфрон и возвращение в СССР.

Ч. 1. Online: https://www.svoboda.org/a/262693.html; Ч. 2. Online: https://www.svoboda. org/a/262899.html (17.06.2017).

Тверитинов, А. Александр Александрович Тверитинов. Крестньй путь на Родину. Online: http://www.history-ryazan.ru/node/5880 (16.05.2018).

Тени замка Арсин. Online: http://www.travel-journal.ru/phenomenons/2/576/ (6.06.2017).

Хубер, П. (1991). Смерть в Лозанне. Новое время, № 21.

Цветаева, М. И. (1990). Письма к Ариадне Берг: (1934-1939). Подг. текста, пер. и примеч. Н. А. Струве. Париж: YMCA-Press.

Эфрон, Г. Дневник. Online: http://thelib.ru/books/efron_georgiy/dnevniki.html (18.05.2018).

Шаховская, 3. А. (1975). Отражения: эссе, письма. Paris: YMCA-Press.

\section{Źródła internetowe}

http://archive.svoboda.org/programs/sp/2002/sp.090802-1.jpg (17.05.2018).

http://litresp.ru/chitat/ru/\%D0\%9A/kudrova-irma-viktorovna/putj-komet-razoblachennayamoroka (20.05.2018).

http://rusrazvedka.narod.ru/base/htm/guct.html (9.06.2017).

http://tsvetaeva.narod.ru/WIN/kudrova/kudrG11.html (10.05.2018).

http://www.history-ryazan.ru/node/5880 (16.05.2018).

http://www.litres.ru (wersja PDF, s. 678).

http://www.livelib.ru/author/13108 (11.06.2017).

http://www.mysilverage.ru/2015/11/29/lebedev-v-perast-perevod-na-fr-m-cvetaevoj/ (15.05.2018).

http://www.rulit.me/author/poznyakov-nikolaj-sergeevich/predannyj-dar-izbrannye-

stihotvoreniya-download-free-199786.html (17.05.2018).

http://www.stihi.ru/2014/08/31/5\%C2\%A0 (17.05.2018).

http://www.vekperevoda.com/1887/poznyakov.htm (17.05.2018).

http://pyсский-путь.pф/store/element.php?IBLOCK_ID=30\&SECTION_ID=0\&ELEMENT_

$\mathrm{ID}=6222(15.05 .2018)$.

https://coollib.com/a/104871 (17.05.2018).

https://fr.m.wikipedia.org/wiki/Brigades_régionales_de_police_mobile (12.05.2018).

https://mtdata.ru/u30/photo2DF9/20320237997-0/original.jpg\#20320237997 (19.05.2018). 
https://nekropole.info/ru/Gertruda-Shildbah (11.05.2017).

https://persons-info.com/persons/TSVETAEVA_Marina_Ivanovna (19.05.2018).

https://ru.wikipedia.org/wiki/Позняков_Николай_Сергеевич (17.05.2018).

https://sites.google.com/t-n-v.com/aru/6-и-журавлев.а-а-тверитинов (16.05.2018)

https://unotices.com/book.php?id=178320\&page=96 (17.06.2017).

https://www.geni.com/people/Антонина-Клепинина/6000000006373302671 (6.06.2017).

https://www.persee.fr/doc/cmr_0008-0160_1991_num_32_2_2282 (11.05.2018).

www.livelib.ru/author/17617/top-irma-kudrova (13.05.2018). 


\section{ANEKS}

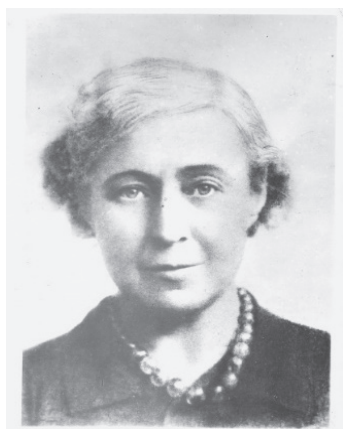

Marina Cwietajewa

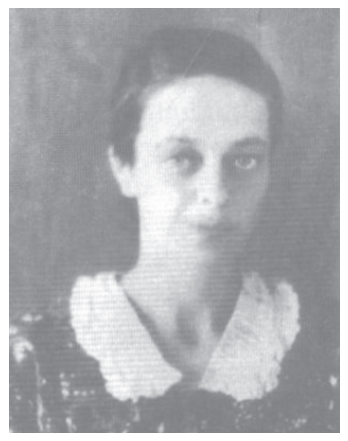

Ariadna Efron

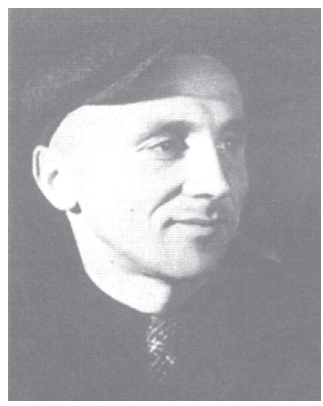

Nikołaj Afanasow

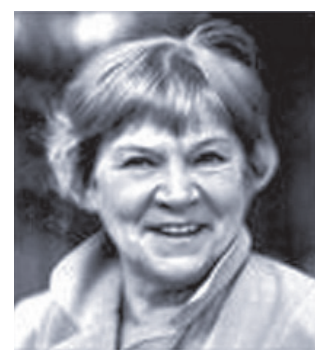

Irma Kudrowa

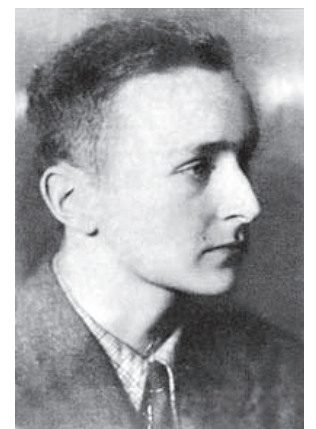

Gieorgij Efron

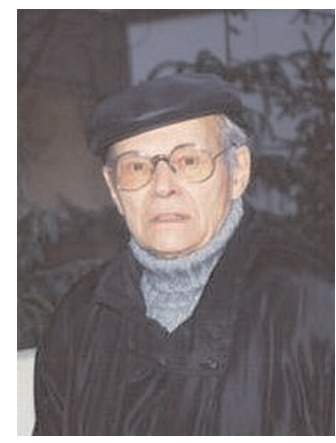

Kiriłł Chienkin

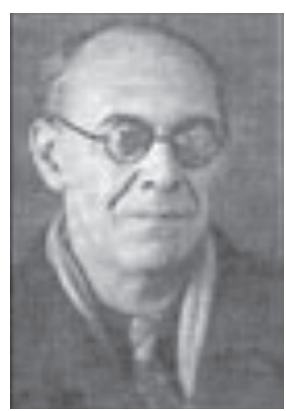

Nikołaj Pozniakow

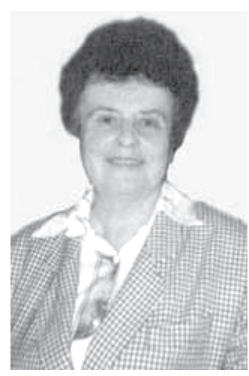

Anna Saakianc 


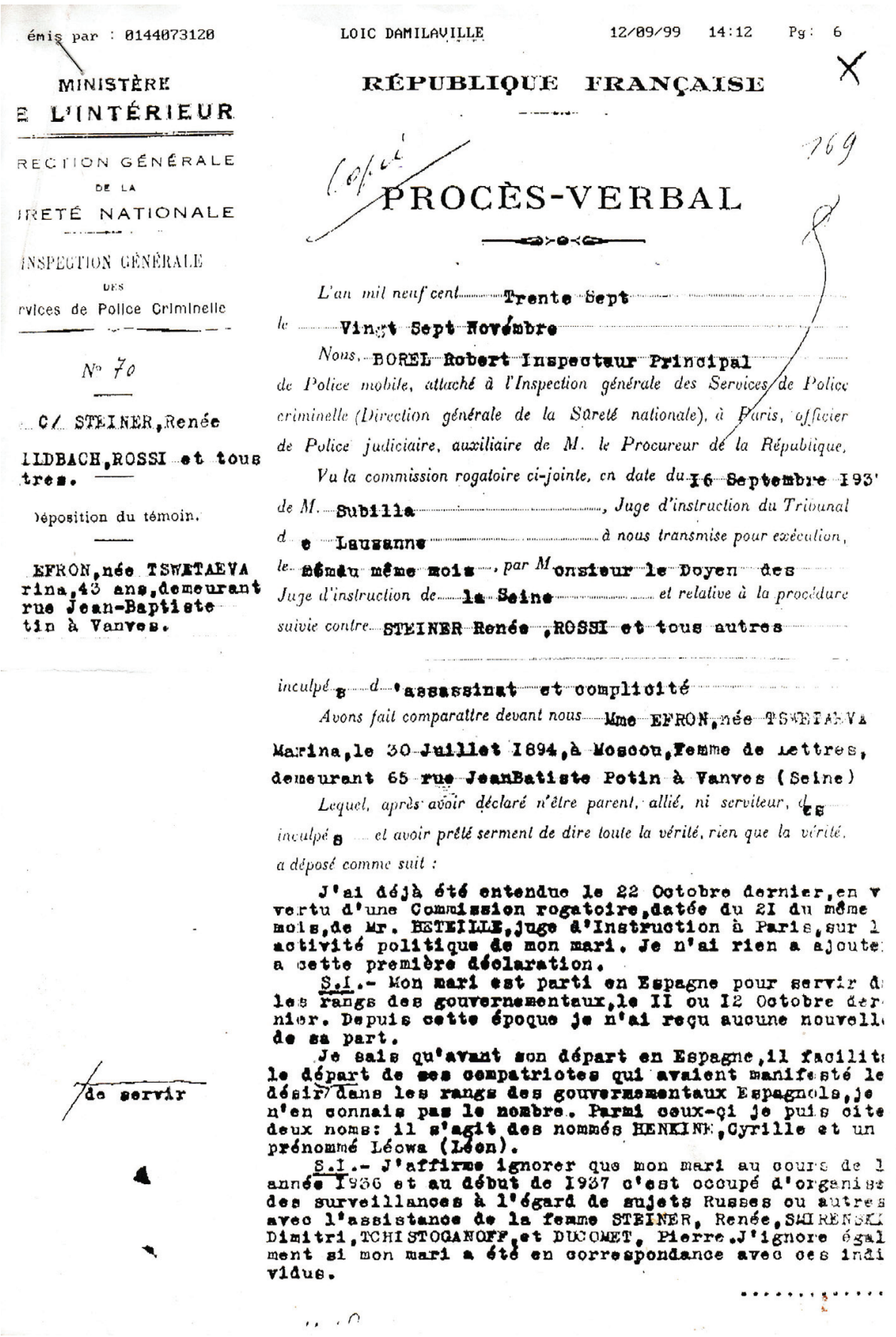

Ryc. 1. Pierwsza strona protokołu przesłuchania Mariny Cwietajewej w paryskiej prefekturze w dniu 27 listopada 1937 roku 


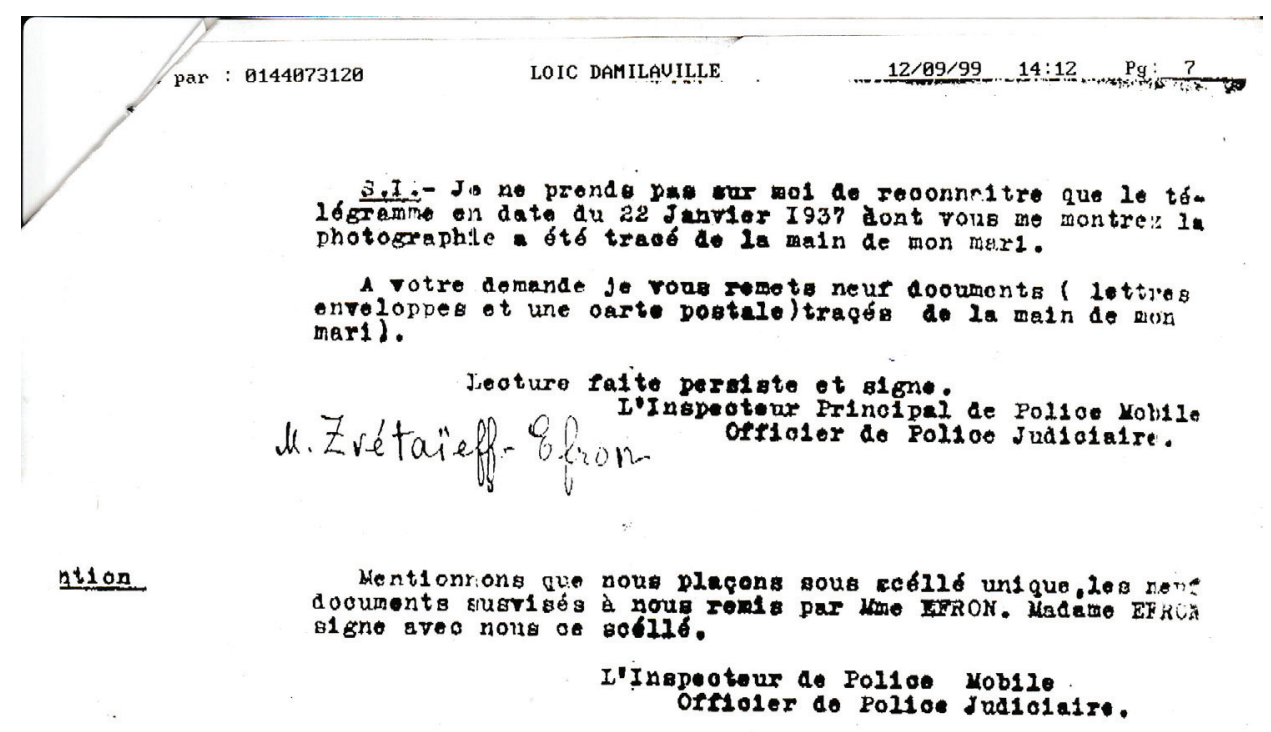

Ryc. 2. Druga strona protokołu przesłuchania Mariny Cwietajewej w paryskiej prefekturze w dniu 27 listopada 1937 roku 


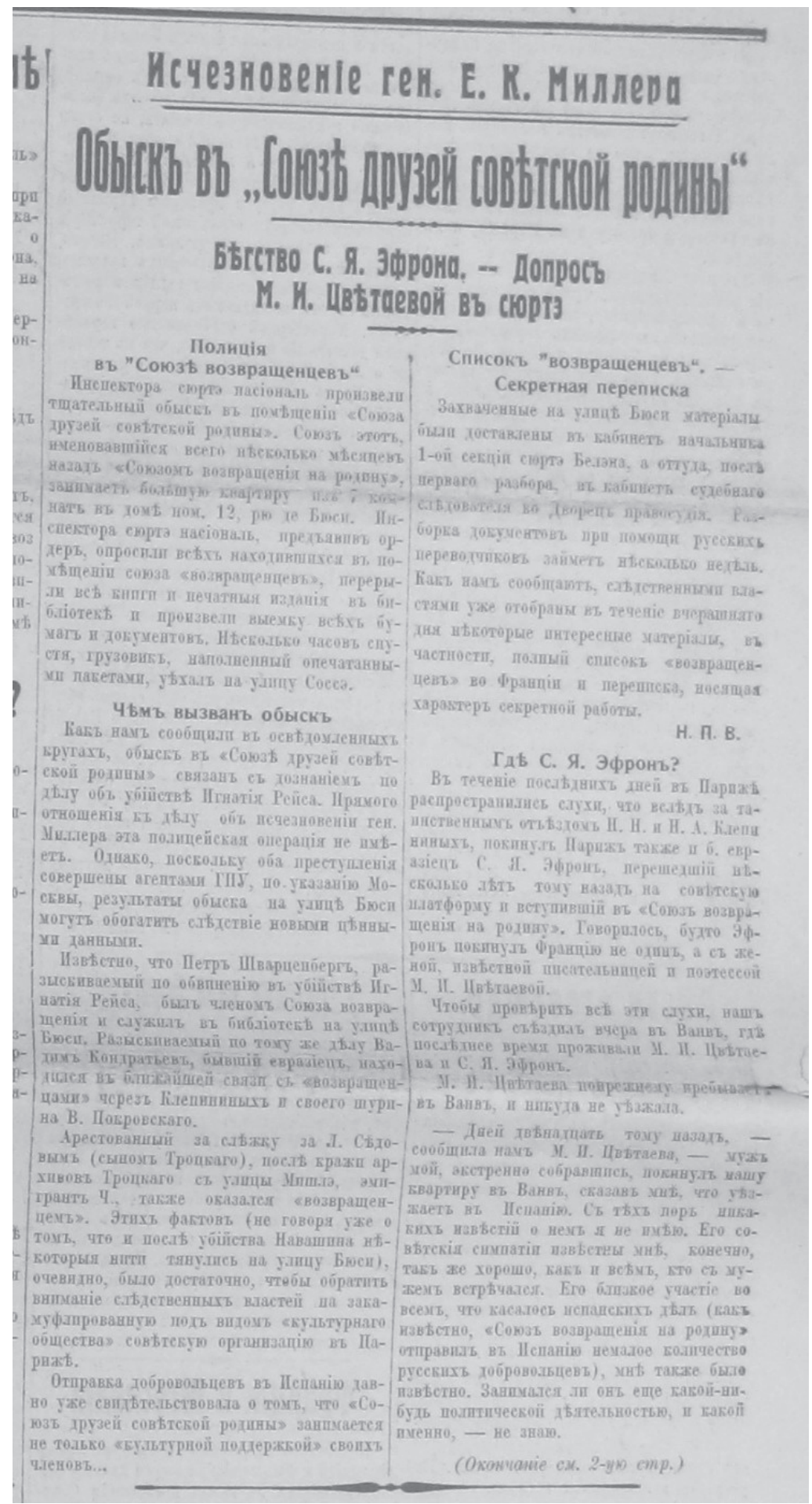

Ryc. 3. Fragment pierwszej strony gazety „Poslednije nowosti” (1937, nr 6056, z 24 X) z artykułem na temat przeszukania w pomieszczeniu należącym do „Związku Przyjaciół Radzieckiej Ojczyzny” 


\title{
Исчезновение ген. Е. К. Миллера Обыск в «Союзе друзей советской родины»
}

\author{
Бегство С. Я. Эфрона. - Допрос \\ М. И. Цветаевой в сюртэ
}

\begin{abstract}
Полиция
в «Союзе возвращенцев»

Инспектора сюртэ насиональ произвели тщательный обыск в помещении «Союза друзей советской родины». Союз этот, именовавшийся всего несколько месяцев назад «Союзом возвращения на родину», занимает большую квартиру из 7 комнат в доме ном. 12, рю де Бюси. Инспектора сюртэ насиональ, предъявив ордер, опросили всех находившихся в помещении союза «возвращенцев», перерыли все книги и печатные издания в библиотеке и произвели выемку всех бумаг и документов. Несколько часов спустя, грузовик наполненный опечатанными пакетами, уехал на улицу Соссэ.
\end{abstract}

\section{Чем вызван обыск}

Как нам сообщили в осведомленных кругах, обыск в «Союзе друзей советской родины» связан с дознанием по делу об убийстве Игнатия Рейса. Прямого отношения к делу об исчезновении ген. Миллера эта полицейская операция не имеет. Однако, поскольку оба преступления совершены агентами ГПУ, по указанию Москвы, результаты обыска на улице Бюси могут обогатить следствие новыми ценными данными.

Известно, что Петр Шварценберг, разыскиваемый по обвинению в убийстве Игнатия Рейса, был членом Союза возвращения и служил в библиотеке на улице Бюси. Разыскиваемый по тому же делу Вадим Кондратьев, бывший евразиец, находился в ближайшей связи с «возвращенцами» через Клепининых и своего шурина В. Покровского.

Арестованный за слежку за Л. Седовым (сыном Троцкого), после кражи архивов Троцкого с улицы Мищлэ, эмигрант Ч., также оказался «возвращенцем». Этих фактов (не говоря уже о том, что и после убийства Навашина некоторые нити тянулись на улицу Бюси), очевидно, было достаточно, чтобы обратить внимание следственных властей на закамуфлированную под видом «культурного общества» советскую организацию в Париже.

Отправка добровольцев в Испанию давно уже свидетельствовала о том, что «Союз друзей советской родины» занимается не только «культурной поддержкой» своих членов»...

\section{Список «возвращенцев». -- Секретная переписка}

Захваченные на улице Бюси материалы были доставлены в кабинет начальника 1ой секции сюртэ Белэна, а оттуда, после первого разбора, в кабинет судебного следователя во Дворце правосудия. Разборка документов при помощи русских переводчиков займет несколько недель. Как нам сообщают, следственными властями уже отобраны в течение вчерашнего дня некоторые интересные материалы, в частности, полный список «возвращенцев» во Франции и переписка, носящая характер секретной работы.

Н. П. В.[акар]

Где С. Я. Эфрон?

В течение последних дней в Париже распространились слухи, что вслед за таинственным отъездом Н. Н. и Н. А. Клепининых, покинул Париж также б. Евразиец С. Я. Эфрон, перешедший несколько лет тому назад на советскую платформу и вступивщий в «Союз возвращения на родину». Говорилось, будто Эфрон покинул Францию неодин, а с женой, известной писательницей и поэтессой М. И. Цветаевой.

Чтобы проверить все эти слухи, наш сотрудник съездил вчера в Ванве, где последнее время проживали М. И. Цветаева и С. Я. Эфрон.

М. И. Цветаева попрежнему пребывает в Ванве, и никуда не уезжала.

Ryc. 4. Rekonstrukcja pełnego tekstu artykułu zamieszczonego w gazecie „Poslednije nowosti” (1937, nr 6056, 24 X, s. 2) o przeszukaniu w pomieszczeniu „Związku Przyjaciół Radzieckiej Ojczyzny" 
- Дней двенадцать тому назад, - муж мой, экстренно собравшись, покинул нашу квартиру в Ванве, сказав мне, что уезжает в Испанию. С тех пор никаких известий о нем я ие имею. Его советские симпатии известны мне, конечно, так же хорошо, как и всем, кто с мужем встречался. Его близкое участие во всем, что касалось испанских дел (как известно, «Союз возвращения на родину» отправил в Испанию немалое количество русских добровольцев), мне также было известно. Занимался ли он еще какой-нибудь политической деятельностью, и какой именно, — не знаю.

\section{[c. 2]}

22 октября, около семи часов утра, ко мне явились четыре инспектора полиции и произвели продолжительный обыск, захватив в комнате мужа его бумаги и личную переписку.

Затем я была приглашена в сюрте насиоиаль, где в течение многих часов меня допрашивали. Ничего нового о муже я сообщить ие могла.

\section{Почему скрылся С. Я. Эфрон}

Одновременно с бегством Н. Н. и Н. А. Клепининых, как это обнаружилось в течение вчерашнего дня , пределы Франции покинул также С. Я. Эфрон, бывший евразиец и видный деятель «Союза возвращения на родину». Исчезновению Клепининых предшествовал 24-часовой допрос Н. А. Клепинина в сюртэ насиональ. Опасаясь, по-видимому, вторичного вызова, Клепинин покинул Париж и увез свою семью. Почему С. Я. Эфрон последовал его примеру?

Некоторый свет на это, может быть, прольют печатаемые ниже заявления бывшего сотрудника Эфрона и Клепинина по авразийскому движению:

- После того, как в евразийской организации произошел в 1929 году так называемый «кламарский раскол» (Сучинский, Арапов, Сергей Эфрон, Родзевич, проф. Карсавин и др.), Н. А. Клепинин остался в правой группе, продолжая сотрудничать с проф. Н. Н. Алексеевым и П. Савицким. Однако, в 1932 году вновь началось личное сближение Клепинина с С. Эфроном.

\section{На службе ГПУ}

С Клепининым в то время я был очень близок, - говорит наш собеседник.
- От него я узнал об участившихся встречах с Эфроном. Клепинин заметно подподал под его влияние, и я не раз предостерегал его. Однажды Клепинин явился ко мне очень взволнованный и сказал: «Эфрон предложил мне работать для ГПУ». Я изумился. Эфрон не скрывал, что стал на советскую платформу и открыто работал в «Союзе возвращения», но - вервбовать людей на службу ГПУ?. «Ты выгнал его», - спросил я? - «Нет, за что же? отвечал Клепинин. - Сергей Яковлевич, очевидно, не придает этому того значения, как мы». - «Но, надеюсь, ты не ответил согласием?». Клепинин возмутился: «Разумеется, нет!». Однако, встречаться с Эфроном он продолжал, о чем сам мне потом говорил.

\section{Проект «евразийского» сборника}

- Весной 1932 года к Н. Н. Клепининой приехали из России гостить ее родители, акад. Насонов с женой. После родительского визита стал заметен резкий перелом. Н. Н. Клепинина перестала скрывать свои симпатии к большевикам. Дружба с Эфроном укрепилась. Они начали чаще бывать друг у друга... Н. А. Клепинин както вызвал меня в кафе и рассказал: «Был опять у меня Эфрон и предложил достать денег на сборник статей с критикой национал-социализма. Сборник должен быть евразийским, с привлечением других известных авторов. Эфрон говорит, что в неделю можно достать тысяч 30-40 франков». - «Откуда деньги?» - спросил я. Клепинин пожал плечами: «Оттуда, разумеется, но переданы будут так, что никто не узнает». - «Но авторам ты это скажешь?». Клепинин ответил: - «Нет, это надо сделать конспиративно». - «Брось! сказал я. - Они тебе ничего не дадут и только запугают. Я решительно уклоняюсь и тебе советую поступить так же». Моральной стороны дела Клепинин, как будто, не учитывал, его увлекала практическая задача. Помолчав, он прибавил: «Эфрон предлагает встретиться с одним советским человеком, который очень интересуется евразийством. Как быть? Стоит встретиться?». — «Не советую»... На том наш разговор и кончился. Клепинин ушел. 


\section{«Анатолий Анатольевич»}

- Прошла неделя, может быть две. Снова встреча с Клепининым, и снова такой же разговор. Видя, что его желание очень сильно, я сказал: «Ну, что-ж, иди! Ничего из этого только не выйдет». «Со-ветский человек хотел с тобой поговорить». - «Ну, нет!...». Я отказался наотрез. Через некоторое время от самого Клепинина узнал, что встреча произошла. Эфрон устроил свидание в итальянском ресторане на бульваре Сэн-Мишель. «Советский человек назвался Анатолием Анатольевичем Краснокупским, бывшим военным. У него, кроме того, была другая фамилия (армянская), по которой его можно было вызвать по телефону из полпредства. «Анатолий Анатольевич» совершенно очаровал Клепинина... «Это совсем наш человек! Отлично во всем разбирается, верно смотрит на вещи, совсем не большевик», - рассказывал Клепинин с восторгом. - «О чем же вы говорили?». - «Об евразийстве, проектировали разные издания»...
Изданий, насколько мне известно, не вышло. Через некоторое время Клепинин перестал рассказывать о встречах и вообще отошел от меня. Мы почти не видались. Эфрон зачастил к Клепининым, и если у Н. А. был период сомнений, то он окончился с обедом в ресторане у Орлеанских ворот. - оба Клепинины, Эфрон и «Анатолий Анатольевич» - летом 1932 года.

Несколько месяцев спустя, как известно, последовало исключение Н. Н. и Н. А. Клепининых из евразийской организации за то, что они вместе с В. Кондратьевым и Н. А. Перфильевым, «самовольно, во фракционнном порядке, без оповещения евразийской организации, как целого, вступили в сотрудничество с враждебной евразийству организацией».

Н. П. В[акар] 


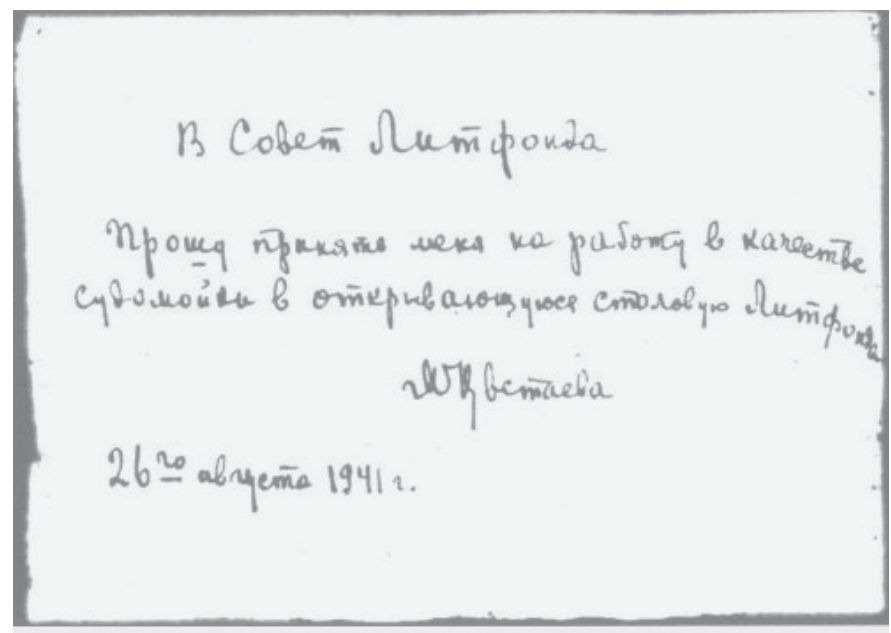

Ryc. 5. Prośba Mariny Cwietajewej o przyjęcie do pracy w stołówce Litfondu w charakterze pomywaczki z 26 sierpnia 1941 roku (na 5 dni przed popełnieniem samobójstwa)

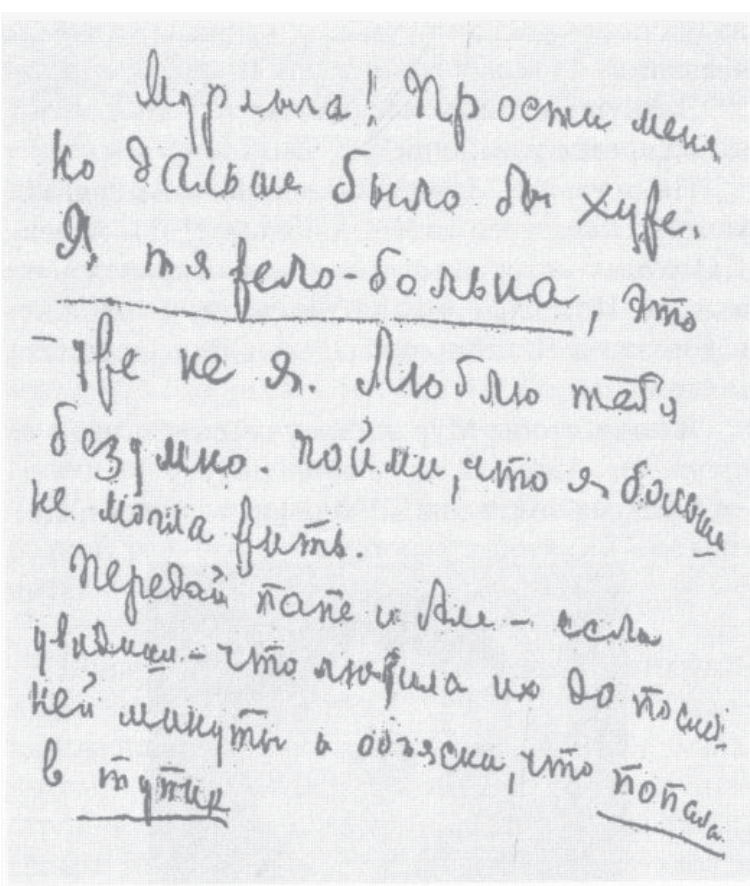

Ryc. 6. Przedśmiertny list Mariny Cwietajewej do syna Gieorgija z 31 sierpnia 1941 roku

(„Murłyga! Wybacz mi, lecz dalej byłoby gorzej. Jestem ciężko chora, to już nie jestem ja. Kocham ciebie bez pamięci. Zrozum, że dłużej nie mogłam żyć. Przekaż ojcu i Ali — jeśli ich zobaczysz —że kochałam ich do ostatniej minuty i wyjaśnij, że znalazłam się w ślepym zaułku”). Na podstawie książki Irmy Kudrowej Szlak komet. Zdemaskowana mitrega (Путь комет. Разоблаченная морока) 